WSRC-TR-91-444, Rev. 3

\title{
Possible Explosive Compounds in the Savannah River Site Waste Tank Farm Facilities
}

by

D. T. Hobbs

Westinghouse Savannah River Company

Savannah River Site

Aiken, South Carolina 29808

\section{RECEIVED \\ APR 212000 \\ OSTI}

DOE Contract No. DE-AC09-89SR18035 \& DE-AC09-96SR18500

This paper was prepared in connection with work done under the above contract number with the U. S.

Department of Energy. By acceptance of this paper, the publisher and/or recipient acknowledges the U.S.

Government's right to retain a nonexclusive, royalty-free license in and to any copyright covering this paper, along with the right to reproduce and to authorize others to reproduce all or part of the copyrighted paper. 


\section{DISCLAIMER}

This report was prepared as an account of work sponsored by an agency of the United States Government. Neither the United States Government nor any agency thereof, nor any of their employees, makes any warranty, express or implied, or assumes any legal liability or responsibility for the accuracy, completeness, or usefulness of any information, apparatus, product or process disclosed, or represents that its use would not infringe privately owned rights. Reference herein to any specific commercial product, process or service by trade name, trademark, manufacturer, or otherwise does not necessarily constitute or imply its endorsement, recommendation, or favoring by the United States Government or any agency thereof. The views and opinions of authors expressed herein do not necessarily state or reflect those of the United States Government or any agency thereof.

This report has been reproduced directly from the best available copy.

Available for sale to the public, in paper, from: U.S. Department of Commerce, National Technical Information Service, 5285 Port Royal Road, Springfield, VA 22161 phone: (800) 553-6847

fax: (703) 605-6900

email: orders@ntis.fedworld.gov

online ordering: http://www.ntis.gov/ordering.htm

Available electronically at http://www.doe.gov/bridge Available for a processing fee to U.S. Department of Energy and its contractors, in paper, from: U.S. Department of Energy, Office of Scientific and Technical Information, P.O. Box 62, Oak Ridge, TN 37831-0062

phone: (865)576-8401

fax: $(865) 576-5728$

email: reports@adonis.osti.gov 
Distribution:

S. M. Aleman, 703-H

B. N. Attaway, 773-A

M. J. Barnes, 773-A

C. S. Boley, 703-H

T. E. Britt, 703-H

T. B. Caldwell, 742-4G

M. C. Chandler, 703-H

V. G. Dickert, 703-H

L. O. Dworjanyn, 735-11A

S. D. Fink, 773-A

F. F. Fondeur, 773-A

M. S. Hay, 773-A

D. T. Hobbs, 773-A

G. J. Hutchens, 703-H

M. D. Johnson, 703-H

B. L. Lewis, 703-H

T. J. Lex, 703-H

T. M. Monahan, 703-H

J. P. Morin, 703-H

T. A. Nance, 723-A

L. M. Nelson, 773-43A

L. M. Papouchado, 773-A

T. B. Peters, 770-A

R. H. Ross, 703-H

W. L. Tamosaitis, 773-A

M. J. Turek, 703-H

T. C. Temple, 703-H

W. B. Van Pelt, 773-43A

D. D. Walker, 773-A

W. R. Wilmarth, 773-42A

STI, 703-43A

WPTS Files, 773-A c/o C. C. Canada, 773-A 
WSRC-TR-91-444

Revision 3

Keywords: Chemistry,

Gases,

Liquids,

Solids,

Flammable,

Hazards,

Radioactive

\section{POSSIBLE EXPLOSIVE COMPOUNDS IN THE \\ SAVANNAH RIVER SITE WASTE TANK FARM FACILITIES (U)}

D. T. Hobbs

Savannah River Technology Center

Date: February 15, 2000

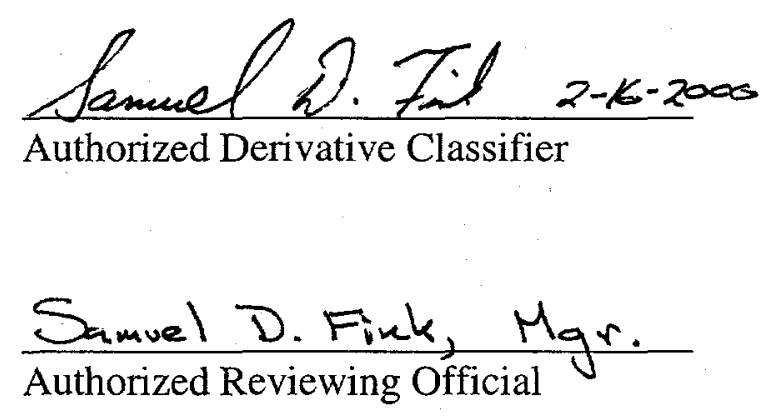

Westinghouse

Savannah River Company

Aiken, SC 29808

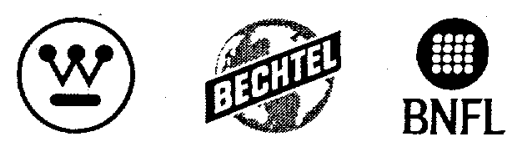


Author

$\frac{\text { D.T.J/h }}{\text { D. T. Hobbs, WPTS }} \frac{2 / 16 / 00}{\text { Date }}$

\section{Technical Review}

$\frac{\text { Rusell I. Coling }}{\text { R. E. Eibling, ITS }} \frac{2 / 22 / 2000}{\text { Date }}$

\section{Approvals}

W.B. Nan Pect

W. B. Van Pelt, Level 4 Manager, WPTS
$2-23-00$

Date

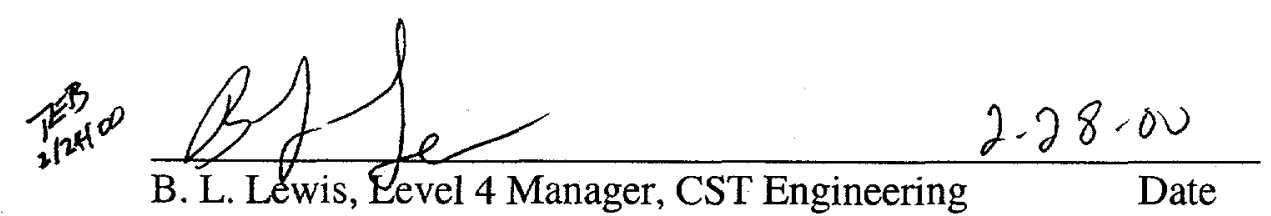




\section{CONTENTS}

Summary

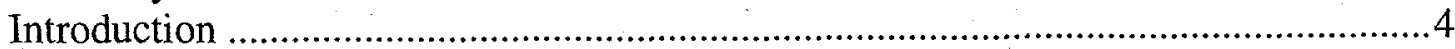

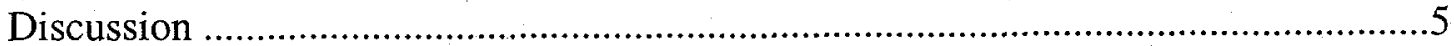

General Description of Waste Storage and Processing......................................... 5

Waste Constituents ..................................................................................... 8

Possible Classes of Explosive Compounds....................................................... 10

Effects of Radiation on Explosive Compounds ........................... 12

Classes Known to Exist but Controlled .........................................................12

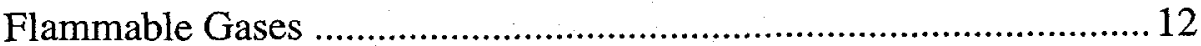

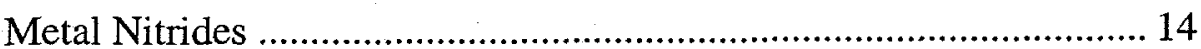

Ammonia Compounds and Derivatives ……………………............. 16

Organic Compounds........................................................................18

Classes that Are Not a Hazard ...................................................................22

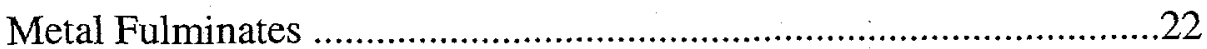

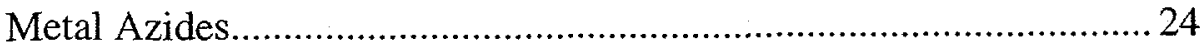

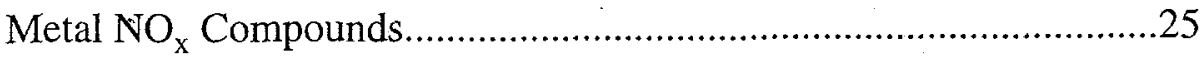

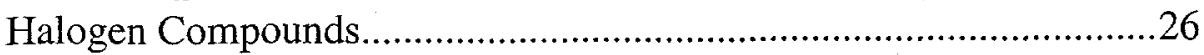

Metal Amine Complexes ................................................................. 27

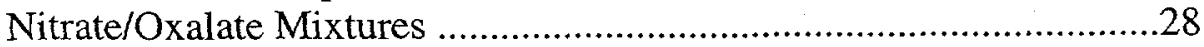

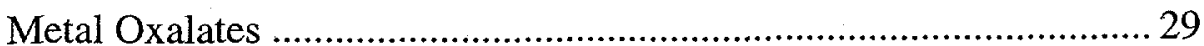

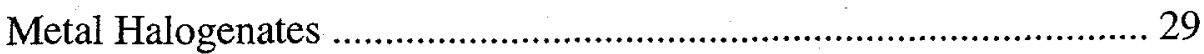

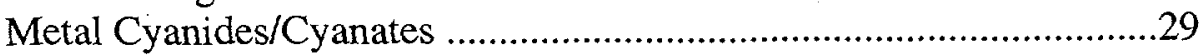

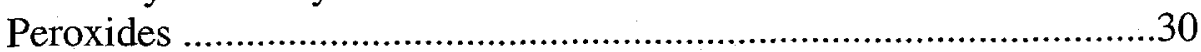

Metal Acetylides .............................................. 32

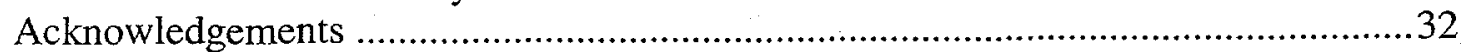

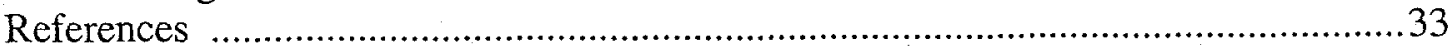

Appendix 1. Supernatant Liquid Composition .......................................................41

Appendix 2. Average and Maximum Projected Weight Percent of Insoluble ........... 42 Components of Sludge

Appendix 3. Comprehensive List of Conceivable Explosive Compounds ................ 43

Table I. Miscellaneous Added Chemicals and Chemical Reaction Products ........... 8

Table II. Conceivable Explosive Compound Classes in SRS Waste Tanks ............11

Table III. Compounds That May Exist in the DWPF Recycle Stream..................... 12

Table IV. Organic Compounds Present in DWPF Off-Gas Condensates.............. 21 


\section{SUMMARY}

Based on a comparison of the known constituents in high-level nuclear waste stored at the Savannah River Site (SRS) and explosive compounds reported in the literature, fifteen classes of compounds were identified as conceivably being present in tank farm operations. Appendix 3 provides a comprehensive list of conceivable explosive compounds. Of the fifteen classes of explosive compounds, eleven classes -- metal fulminates, metal azides, halogen compounds, metal-amine complexes, metal $\mathrm{NO}_{\mathrm{x}}$ compounds, nitrate/oxalate mixtures, metal oxalates, metal oxohalogenates, metal cyanides/cyanates, peroxides, and metal acetylides -- are not a hazard because these compounds cannot be formed or accumulated in sufficient quantity, or are not reactive at the conditions that exist in the tank farm facilities. Four classes of explosive compounds, flammable gases, metal nitrides, ammonia compounds and derivatives, and organic compounds, have the potential to build up to concentrations at which an observable reaction may occur. Controls have been in place for some time to limit the formation or control the concentration of these classes of compounds.

Recent work has focused on safety issues associated with the storage of dry sludge and the introduction of organic compounds into the tank farm. Work completed to date indicates no additional controls are needed to ensure safe operations for tanks containing dried sludge and for the introduction of organic compounds into tank farm operations. This report will be revised upon completion of current testing investigating the radiolytic stability of additional energetic materials (e.g., Millon's Base) and the analysis of tank farm samples for volatile and semi-volatile organic compounds.

\section{INTRODUCTION}

Since 1970 , many studies have been conducted concerning the potential for explosive compounds in tank farm operations including ammonium nitrate, metal oxalates, and silver and mercury compounds. The study currently in progress is the most comprehensive to date, encompassing all previous studies and extending the scope to include all compounds that could be formed from the known species in SRS wastes. In addition to waste storage, the study also considers waste removal and waste processing operations.

The total number of possible explosive compounds is so large that it would not be useful to list them all here. Instead, only those compounds are listed that are known to be present or could conceivably be formed from material that is known to be present in the waste. The general approach to the problem is: (1) identify all of the constituents that are known to be present in the waste together with those that might be present from possible chemical and radiolytic reactions, (2) determine the compounds that could be formed from these constituents, (3) compare these compounds with those listed in the literature, and (4) assess the formation and stability of these compounds against the conditions existing in the tank farm facilities. 


\section{DISCUSSION}

General Description of Waste Storage and Processing

The Savannah River Site has two high-level nuclear waste storage areas. These areas are located in F-Area and H-Area adjacent to the separations canyons. The storage facilities consist of 49 underground carbon steel storage tanks, three waste evaporators, and undergfound transfer lines. The transfer lines allow waste to be transported from the waste generator to the tanks, from tank to tank, from tanks to evaporators, between the two tank farms, and to the Defense Waste Processing and Saltstone facilities.

High-level waste (HLW) generators include chemical separations reactors, decontamination facilities, the Effluent Treatment Facility (ETF), the Receipt Basin for Off-Site Fuels (RBOF), analytical laboratories, research and development laboratories and the Defense Waste Processing Facility (DWPF). Historically, chemical separations have produced the majority of the HLW at the SRS. However, the DWPF is now a major producer of waste that enters into the Tank Farm.

All HLW must meet the waste acceptance criteria (WAC) established for the operation of the two tank farms [1]. Each generator has developed a waste compliance plan to establish that the waste meets the WAC [2-5]. WAC criteria include requirements for corrosion protection, prevention of flammable/explosive species accumulation, regulatory compliance, criticality safety, radionuclide content and downstream facility acceptance criteria.

Before waste is transferred into a tank, the waste generator is required to make the waste alkaline to prevent general corrosion of the waste tanks. The degree of alkalinity is determined by the chemical composition of the waste. For Separations waste, the free hydroxide concentration in fresh waste must be greater than 1.2 molar. Because of the high $\mathrm{pH}$, the majority of the metal ions precipitate as metal hydroxides or hydrous metal oxides.

Fresh waste transfers into fresh-waste receipt tanks. Upon standing - the precipitated metal oxides and hydroxides, referred to as sludge, settle at the bottom of the tank. The supernatant liquid above the settled sludge is decanted and sent to an evaporator for concentration. After evaporation, the concentrated liquid transfers to a concentrate receipt tank and cools. Upon cooling, salts crystallize from the concentrated supernatant liquid. After a period of time, the cooled concentrated supernatant liquid is decanted and returned to the evaporator feed tank.

Historically, operating practices limited the drying of waste during the storage and handling operations. Generally a layer of supernatant liquid is maintained on top of the sludge or salt in each tank. However, several tanks do not have measurable quantities of freestanding liquid over the solids. Solids in these tanks will have reduced water content due to evaporation. The degree of dryness is unknown, as there have been no attempts to sample and analyze the solids for water content. The solids are not expected to be completely dry throughout the solids layer since the waste temperatures are less than 75 ${ }^{\circ} \mathrm{C}[6]$. 
The High Level Waste Division declared a potential inadequacy in the safety analysis (PISA) for the dry sludge tanks in 1997 (currently tanks 5F, $12 \mathrm{H}$ and $15 \mathrm{H}$; tanks 6F and $8 \mathrm{~F}$ formerly were dry, but have recently been rewetted) due to concerns related to the release of dry sludge particles [7]. Explosive compounds are generally more reactive when dry $[8,9]$. An extensive research program initiated in 1998 to assess storage of dried sludge [10]. Four reports have issued detailing the results of characterization of three sludge samples archived at the SRTC and calorimetry and impact testing of simulated sludge samples $[11,71,112,119]$. Based on the experimental findings, the authors concluded the following.

- Differential scanning calorimetry analysis of Tank 8F, Tank $12 \mathrm{H}$ and Tank $15 \mathrm{H}$ samples showed no exothermic behavior to temperatures as high as $400{ }^{\circ} \mathrm{C}$.

- Experimental evidence does not preclude the formation of energetic materials in the waste tanks during dry storage. However, simulated sludge with conservatively high concentrations of mercury and silver failed to show any exothermic behavior without deliberate addition of such compounds.

- Mixtures of sludge with mercury oxalate showed no net exothermic behavior under the conservative conditions tested. Testing with mercury fulminate required addition of relatively high concentrations in simulated sludge to provide a relatively low energy exothermic reaction.

- Calorimetry data suggest the presence of the principal organic compounds of interest within simulated sludge does not enhance the energetic behavior of the material, even when both the organic and the energetic standard (i.e., mercury oxalate or mercury fulminate) exist in conservatively high concentrations.

- Silver nitride, mercury oxalate and mercury fulminate decompose under tank conditions of radiation and alkalinity and, therefore, cannot accumulate to present an explosion hazard in dry sludge tanks.

Based upon the recommendation made by the Energetic Materials Research and Testing Center [118], testing continues to determine the effects of extended contact with hydroxide and radiation effects on the energetic behavior of simulated sludges and Millon's base. This work will confirm that the tank environment (high hydroxide and radiation field) destroys energetic materials introduced or formed in Tank Farm facilities.

All transfer lines are sloped to ensure that waste drains to a waste tanks or other acceptable storage location (e.g., pump tank) after transfer. Experience has shown that solids do not accumulate in transfer lines except in evaporator concentrate lines, which handle hot, supersaturated salt solutions. These lines plug occasionally due to salt crystallization. To avoid plugs, evaporator concentrate lines are flushed frequently to prevent the accumulation of solids. Evaporators are also flushed when shut-down to remove as much residual waste as possible. Small amounts of dried waste can be produced when waste has leaked into a secondary enclosure and evaporates. Examples of leaked waste that possibly have formed dried deposits include (1) leaks from the primary tank into the tank annulus, (2) leaks into the waste feed-jet enclosure, and (3) leaks into the evaporator cell. 
Two additional processes, In-Tank Precipitation (ITP) and Extended Sludge Processing (ESP), have been developed to prepare the high-level waste for disposal. These processes are performed in waste tanks that have been modified for chemical processing. Sludge wastes are slurried with inhibited water $(0.015 \mathrm{M}$ sodium hydroxide $)$ and transferred from storage tanks into the ESP tanks. Salt waste is dissolved with inhibited water and transferred to the ITP tank for removal of soluble radionuclides.

In ITP, supernatant liquid is treated with sodium tetraphenylborate and monosodium titanate to remove cesium and strontium. The resulting solids containing cesium and strontium are separated from the liquid by filtration and washed with water to reduce the soluble salt content. The washed solids are stored in a waste tank until transferred to the DWPF for processing into a borosilicate glass wasteform. The decontaminated supernatant liquid is stored in a separate waste tank until transferred to the Saltstone facility for processing into a cement wasteform. Wash waters are recycled in the process so as to dilute concentrated supernatant liquid.

The ITP process became operational in 1995. However, as the result of operational problems, the process was discontinued in January 1998. Tank $48 \mathrm{H}$ stores the precipitate slurry produced from the 1983 Demonstration and Batch 1 . Tank $49 \mathrm{H}$ currently stores wash water from the 1983 Demonstration.

Evaluation of salt processing alternatives selected four possible processes for treating soluble wastes; (1) Small Tank Tetraphenylborate (STT) process, (2) Non-elutable Ionexchange (NIX), (3) Caustic Side Solvent Extraction (CSSE) and (4) Direct Grout (DG) [109]. New facilities will be constructed for each option. The STT process features the same process chemistry as previously described for the ITP process. The major difference is that in the STT process, precipitation will be carried out in relatively small continuously stirred tank reactors (ca. 20000 gallons) versus a 1.3 million gallon waste tank. The NIX process features a non-eluatable ion-exchange material, crystalline silicotitanate (CST) to remove radiocesium from the radioactive waste solution. The CSSE process features a novel extraction system that selectively removes cesium from alkaline waste solutions. The DG process would not remove the radiocesium from the liquid waste, but incorporate all liquid waste in a grout formulation. All four options would include strontium and alpha removal utilizing the inorganic sorbent monosodium titanate. In the STT process, the MST step occurs at the same stage as the tetraphenylborate precipitation. For the other three options, the MST strike proceeds the cesium separation or immobilization stage.

In ESP, the soluble salts in sludge waste are removed by diluting the waste with water, mixing, allowing the slurry to settle and decanting off the supernatant liquid. This method of washing is continued until the soluble salt content meets the requirement for processing in the DWPF. For sludge waste containing high levels of aluminum, sodium hydroxide is added and the mixture heated to dissolve the alumina. After dissolution of the alumina, the sludge is washed with water to remove soluble salts. Wash waters are evaporated or recycled into waste removal operations. 


\section{Waste Constituents}

High-level nuclear waste is stored at the SRS in a highly alkaline form in underground carbon steel tanks. Because of the high $\mathrm{pH}$, the waste consists of two phases, a liquid phase, comprised of water-soluble salts, and a solid phase or sludge, comprised of hydrous oxides of various metal ions. Appendices 1 and 2 list the compounds known to be present in the supernatant liquid and the sludge fractions of the waste. The average and bounding values are based on analysis of samples taken from waste tanks, essential material records and process knowledge. The average values assume a perfect blend of all waste $[12,13]$.

Table 1 lists other species and compounds that may be present in radioactive waste as a result of reactions occurring during chemical processing, miscellaneous additions to waste tanks and new waste processing operations in support of the DWPF. The ammonia/ammonium ion in the waste is from three sources: (1) impurities in the process chemicals, (2) reaction of nitrogen-containing chemicals such as sulfamic acid and hydrazine during chemical processing and (3) reaction of nitrite and formic in the presence of noble metals in the DWPF. Of the first two sources which originate in separations operations, estimates indicate $>90 \%$ of the ammonia/ammonium ion comes from the second source [14].

Table I. Miscellaneous Added Chemicals and Chemical Processing Reaction Products

Ammonia/Ammonium ion

Hydroxylamine

Tri-n-butyl phosphate

Mono-n-butyl phosphate

Gluconic acid

Ion-exchange Resins

Hydrogenated tallow glycerides

2,4,7,9-tetramethyl-5-decyne-4,7-diol

Tetraphenylborate salts ${ }^{a}$

Phenol $^{b}$

Diphenylboronic Acid ${ }^{b}$

Aniline

Terphenyl $^{b}$
Hydrazine

n-Paraffin

Di-n-butyl phosphate

n-Butanol

Ascorbic Acid

Polydimethylsiloxane

Methylcellulose

Ethylene glycol

Benzene $^{b}$

Triphenylborane

Monophenylborinic Acid ${ }^{b}$

Biphenyl $^{b}$

\footnotetext{
a Tetraphenylborate salts are present in Tanks $48 \mathrm{H}$ and Tank $49 \mathrm{H}$ from the 1983 Demonstration and Batch 1 operations of the ITP process.

${ }^{b}$ Decomposition products from tetraphenylborate.
} 
Hydrazine and hydroxylamine are chemical reductants, which have been used in the chemical separations processes. n-Paraffin, tri-n-butyl phosphate, and ion-exchange resins are also used in the separations processes for the recovery and purification of uranium and plutonium. Gluconic acid was used briefly in chemical separations during the late 1950 's, but has not been used since that time.

Ascorbic acid is used in the Separations processes for actinide valence adjustment. Very little ascorbic acid is present in the high-level waste. Ascorbic acid hydrolyzes rapidly in both acidic and basic solutions. Hydrolysis products include oxalic acid and smaller molecular weight organic acids. Further hydrolytic and radiolytic reactions with the organic acids produce carbon dioxide [15].

During Separations processing, excess hydrazine and hydroxylamine are destroyed by chemical reactions with nitrate and nitrite. $n$-Paraffin is volatile and effectively removed prior to discharge to the tank farm by evaporation in canyon evaporators. Any remaining $\mathrm{n}$-paraffin is removed upon evaporation in the tank farm. Thus, the concentration of hydrazine, hydroxylamine, and n-paraffin in evaporated waste is extremely low [27].

Through 1984, it has been estimated that 395,000 kilograms of tri-n-butyl phosphate (TBP) had been discharged to the tank farm [16]. Hydrolysis and radiolytic decomposition of the TPB produces n-butanol, di-n-butyl phosphate, mono-n-butyl phosphate, carbon dioxide, and inorganic phosphates.

Ion-exchange resins that have been used at SRS in production facilities include polystyrene, macroporous styrene-divinylbenzene, and polyvinylpyridine. An estimated 56,400 kilograms of ion-exchange resin has been sent to the tank farms though 1984 [16]. Individual transfers of resins are limited to the total quantity of resin contained in an ionexchange column (generally less than 50 kilograms). Approximately two-thirds of the resin was digested with potassium permanganate prior to transfer. The digestion process chemically breaks the resin into smaller molecular weight fragments and solubilizes the resin by formation of hydroxyl and carboxylate groups. During storage, radiolysis slowly converts resins to carbon dioxide, hydrogen, and volatile monomeric organic compounds such as trimethylamine and methane. The rate of production of flammable radiolysis products is slow and much lower than that for the production of hydrogen by the radiolysis of water $[17,18]$.

High-level waste evaporators utilize defoamers during concentration of supernatant liquids to prevent plugging of the dip tubes in the evaporator vessel. Defoamers utilized at SRS include Dow Corning Antifoam B Emulsion and Dow Corning H-10 Emulsion. Both defoamers are chemically similar in composition and contain water, polydimethlysiloxane and hydrogenated tallow glycerides. Antifoam B Emulsion also contains methycellulose.

Sodium tetraphenylborate was used to remove cesium from salt solution in the ITP process. Radiolytic decomposition of the NaTPB produces benzene, triphenylborane, diphenylborinic acid, monophenylboronic acid, phenol and smaller amounts of biphenyl, terphenyl, and aniline. Phenol is the predominant organic compound produced in the 
Defense Waste Processing Facility from hydrolysis of the ITP produced slurry. Phenol and other trace organic compounds are returned to the tank farm in a process overheads recycle stream. Because of the high $\mathrm{pH}$, essentially all of the phenol is converted to phenoxide.

The ITP process has been discontinued. However, organic compounds from the use of sodium tetraphenylborate during the 1983 Demonstration and Batch 1 of the ITP operation are present in decreasing amounts in three tanks, $48 \mathrm{H}, 49 \mathrm{H}$ and $50 \mathrm{H}$. As discussed previously, WSRC is currently evaluating four options for processing radioactive waste solutions. Since there has not been a decision on which process will be implemented, we evaluated the possible impacts of chemicals used in each process on tank farm operations in this report.

CST is a non-elutable ion-exchanger material that is comprised chiefly of silicon, titanium and oxygen with smaller amounts of proprietary elements. The engineered form contains a binder to assemble the small CST primary particles into a relatively large aggregate that can be used in an ion-exchange column with reasonable superficial liquid velocities and pressure drops. A small fraction of the elemental components of the CST would be expected to return to the tank farm in the DWPF recycle stream.

The CSSE system employs a solvent system comprised of a calixarene crown, bis(tertoctylbenzo-crown-6)calix [4]arene (BoBCalixC6) and a modifier, 1-(1,1,2,2tetrafluoroethoxy)-3-(4-tert-octylphenoxy)-2-propanol (Cs-3), dissolved in a branched aliphatic hydrocarbon diluent, Isopar ${ }^{\circledR} \mathrm{L}$ [110]. Plans include adding trioctylamine to the solvent to enhance cesium removal from the solvent during the stripping stage of the process. Small amounts of these organic compounds would be sent forward with the decontaminated salt solution and disposed in Saltstone. Very small amounts of these organic compounds would be introduced in the tank farm facilities resulting from solvent cleanup and return of the DWPF recycle stream.

\section{Possible Classes of Explosive Compounds}

Fifteen classes of explosive compounds were identified as conceivably being present in SRS tank farm facilities by comparing the list of known elements and species in current or planned chemical processing operations with explosive compounds and reactions listed in the literature $[8,9,19]$. Table II provides a list of the fifteen classes of compounds. Appendix 3 provides a comprehensive list of conceivable explosive compounds.

Eleven of the fifteen classes were eliminated as possible hazards based on a review of the formation and stability of individual compounds at the conditions that exist in storage and processing operations and experimental testing. The eleven classes are metal fulminates, metal azides, metal $\mathrm{NO}_{\mathrm{x}}$ compounds, halogen compounds, metal-amine complexes, nitrate/oxalate mixtures, metal oxalates, metal oxohalogenates, metal cyanides and cyanates, and peroxides. Four classes, flammable gases, metal nitrides, ammonia compounds and derivatives, and organic compounds have the potential to build up to concentrations at which an observable reaction might occur. Specific compounds of these three classes include hydrogen, benzene, silver nitride, ammonium nitrate, ammonium nitrite, and potassium tetraphenylborate. Administrative and engineering 
controls have been in place for some time to limit the formation or concentration of these compounds in tank farm facilities.

Table II. Conceivable Explosive Compound Classes in SRS Waste Tanks

\author{
KNOWN TO EXIST BUT CONTROLLED \\ - Flammable Gases \\ - Metal Nitrides \\ - Ammonia Compounds and Derivatives \\ - Organic Compounds
}

\author{
NOT POSSIBLE \\ - Metal Fulminates \\ - Metal Azides \\ - Metal $\mathrm{NO}_{\mathrm{x}}$ Compounds \\ - Halogen Compounds \\ - Metal-amine Complexes \\ - Nitrate/Oxalate Mixtures \\ - Metal Oxalates \\ - Metal Oxohalogenates \\ - Metal Cyanides/Cyanates \\ - Peroxides \\ - Metal Acetylides
}

Nitrated organic compounds (e.g., nitrophenol and nitrosophenol) have been detected in off-gas streams from laboratory and pilot-scale tests simulating DWPF operations and in qualification tests conducted at the DWPF. The origin of the aromatic compounds arises from processing tetraphenylborate slurries received from the ITP process in the Salt Processing Cell of the DWPF. ITP operations halted in 1998 prior to transfer of any radioactive tetraphenylborate slurries to the DWPF. Thus only minor quantities of aromatic compounds have been collected at the DWPF during cold chemical qualification testing and returned to the tank farm. Nevertheless, significant testing occurred prior to halting ITP operations to determine what concentrations these compounds will be in the recycle stream, and if sufficient quantities can accumulate to present a hazard. Table III provides a list of the specific organic compounds identified and tested in these studies. 


\section{Table III. Compounds That May Exist in the DWPF Recycle Stream upon Introduction of Coupled Operations with the ITP Process}

\author{
Phenol/Phenoxide \\ 1,3,5-Trinitrobenzene \\ 4-Nitrophenol \\ 4-Nitrosophenol \\ 2,4,6-Trinitrophenol \\ 1,3-Dinitrobenzene \\ 4-Nitrodiphenylamine \\ Aniline \\ 2-Phenylphenol \\ 4-Phenyl-azophenol \\ 2-Nitroaniline \\ 4-Nitroaniline
}

\author{
Nitrobenzene \\ 2-Nitrophenol \\ 2-Nitrosophenol \\ 2,4-Dinitrophenol \\ 1,2-Dinitrobenzène \\ 2-Nitrodiphenylamine \\ Dinitrodiphenylamine \\ N-Phenylformamide \\ 4-Phenylphenol \\ Carbazole \\ 3-Nitroaniline
}

\section{Effects of Radiation on Explosive Compounds}

The effects of nuclear radiation on explosives has been studied extensively [ 20 and references cited therein]. Exposure of energetic materials to radiation produces changes in the materials including weight loss, gas evolution, mechanical sensitivity, thermal sensitivity and stability and explosive performance. In general, energetic materials decompose without detonation or deflagration upon exposure to nuclear radiation. Nitrogen triiodide is the only material reported to detonate upon exposure to nuclear radiation. This compound detonated when exposed to either alpha radiation or an electron beam. The detonation was attributed in part to localized heating of the material.

Detonation of energetic materials by exposure to steady-state gamma and neutron irradiation has not been observed. All testing results indicated that steady-state gamma and neutron irradiation slowly decomposes the energetic material resulting in deterioration in the functional performance of the energetic materials. Energetic materials evaluated included both inorganic (including mercury fulminate) and organicbased explosives. The degree and rate of decomposition is dependent on the explosive material. Given the high gamma and neutron irradiation fields in the HLW storage tanks, the likelihood that explosive compounds would remain in a highly energetic form for extended periods of time is extremely low.

\section{CLASSES KNOWN TO EXIST BUT CONTROLLED}

\section{Flammable Gases}

Hydrogen and oxygen are produced in the waste storage tanks as a result of the radiolysis of water. The hydrogen generation rate in SRS waste tanks is bounded at $\leq 6.0 \mathrm{ft}^{3} / \mathrm{million}$ BTU of fission product heat [21]. The hydrogen generation rate also depends upon the concentrations of nitrate and nitrite in solution $[22,111]$. An increase in the nitrate and nitrite concentrations decreases the rate of hydrogen generation. Since nitrate and nitrite are major constituents of the high-level nuclear waste, the hydrogen generation rate in the waste solutions is suppressed relative to that of pure water. 
To prevent the accumulation of explosive mixtures of hydrogen and the buildup of high oxygen concentrations in the vapor space of the waste tanks, all of the tanks are equipped with an active ventilation system. Air is pulled through the tank to maintain a slight negative pressure. Typically, the flow rate of air in the tanks ranges from $100-350 \mathrm{cfm}$.

Hydrogen monitors are installed on all of the Type III waste tanks and the older waste tanks that have received fresh waste. These monitors are set to alarm when the hydrogen concentration reaches $10 \%$ of the lower flammable limit (LFL) in air (4\%) [13]. In the event that the ventilation system is shut down, administrative procedures require that the system be returned to operating condition within a period of time determined by the decay heat load of the tank [21]. For those tanks that do not have permanently installed monitors, the vapor space is sampled on a periodic basis and the concentration of flammable gases determined.

Benzene is a volatile organic compound that can form flammable vapor mixtures with air. The lower flammable limit for benzene in air is $1.3 \%$ [24]. Three forms of benzene, dissolved in aqueous solution, sorbed onto tetraphenylborate (TPB) solids and liquid benzene, are produced by chemical and radiolytic decomposition of TPB salts during the ITP process. Benzene releases to the vapor phase in an attempt to establish equilibrium between the liquid and vapor phases. Continual ventilation of the tank acts to pump the liquid benzene from the liquid phase into the vapor phase and out of the tank. When the formation rate of benzene exceeds the release rate, the solution can reach saturation and a separate liquid benzene phase can form. Increased benzene release occurs upon addition of mechanical energy to the TPB slurry (e.g., operation of mixing pumps) and upon dissolution of TPB solids [114-117].

The ITP processing and storage tanks and the filtrate hold tanks are purged with nitrogen. This will maintain the concentrations of flammable gases below their LFL in air and reduce the oxygen concentration to a level below that which is required to support combustion. Recommended operational safety requirements limit the oxygen concentration in these facilities to less than $6.9 \%$ by volume $[25,26]$. During certain design-basis events, the ventilation system can be lost. Unless the ventilation is restored, the concentration of benzene and hydrogen could increase above the LFL and sufficient oxygen will be exchanged from the outside atmosphere to reach the minimum oxygen concentration required for combustion. For Tank $48 \mathrm{H}$, the inventory of benzene is limited so that following a sudden release of retained benzene and hydrogen, the time to the composite lower flammable limit (CLFL) is 18 days in the absence of inerting and/or ventilation [25]. Tank $49 \mathrm{H}$ operates under a JCO [26]. The current benzene production rate exceeds the rate on which the minimum of 9 days to CLFL [25] was based. Consequently, compensatory controls were established to ensure the preservation of an inert atmosphere [26].

DWPF uses Surfynol ${ }^{\circledR}$ 104E and ITP recommended the use of Surfynol ${ }^{\circledR} 420$ to control foaming in the Late Wash facility. Surfynol ${ }^{\circledR} 420$ was not used in the ITP process prior to halting ITP operations in 1998. Thus, the only source of Surfynol ${ }^{\circledR}$ defoamers in tank farm facilities is currently into the H-Area tank farm from the receipt of the DWPF recycle stream (see Table IV). Tanks $43 \mathrm{H}, 38 \mathrm{H}, 22 \mathrm{H}$ and $21 \mathrm{H}$ normally receive the 
DWPF recycle stream. Liquid waste from Tank $43 \mathrm{H}$ is evaporated in the $2-\mathrm{H}$ Evaporator. The concentrated waste transfers from the evaporator into Tank $38 \mathrm{H}$.

The active ingredient in Surfynol ${ }^{\circledR} 104 \mathrm{E}$ is an acetylenic glycol, 2,4,7,9-tetramethyl-5decyne-4,7-diol dissolved in ethylene glycol. Radiolytic and chemical decomposition of the acetylenic glycol in Surfynol ${ }^{\circledR} 104 \mathrm{E}$ will produce acetylene, other terminal alkynes, methyl isobutyl ketone (MIBK) and low molecular weight alcohols [28, 29]. These organic compounds are volatile and, therefore, would increase the hazard of flammable vapor compositions in tank farm facilities if present in significant quantities.

Bibler and Swingle reported that the time to reach $25 \%$ of the LFL for acetylene/air mixtures in Tank $43 \mathrm{H}$ from the decomposition of 2000 ppm containing Surfynol ${ }^{\circledR} 420$ in 968,000 gallons of waste is 490 hours [30]. Smaller waste volumes (larger tank vapor volumes) increases the time to reach $25 \%$ of the LFL. The maximum concentration of the acetylenic glycol in the DWPF recycle stream from Surfynol ${ }^{\circledR} 104$ is about 20 times lower than that planned for use at the Late Wash facility from Surfynol ${ }^{\circledR} 420$. Consequently, acetylene production will be much slower resulting in a much longer time period before reaching $25 \%$ of the LFL. Thus, the presence of no more than $100 \mathrm{ppm}$ of Surfynol ${ }^{\circledR} 104$ in the DWPF recycle stream is not an explosion hazard upon transfer into tank farm facilities.

Other flammable gases that conceivably are produced in the waste tanks include ammonia, methane, ethane, ethylene, and n-butanol. The amount of ammonia and organic compounds in fresh waste is limited to reduce the possible formation of flammable ammonia and organic vapor mixtures [1]. Recent analyses of samples taken from pump tanks $(3 \mathrm{~F}$ and $5 \mathrm{H})$ and fresh waste receipt tanks $(38 \mathrm{H}, 43 \mathrm{H}, 26 \mathrm{~F}, 33 \mathrm{~F}, 34 \mathrm{~F}$, and 46F) indicate that the total ammonia and organic content is very low [31-33]. Results also indicated no detectable quantities of volatile or semi-volatile organic compounds in any of the samples except for siloxane-type materials in the Tank $38 \mathrm{H}$ sample. The siloxane materials are not a flammability hazard and may have originated from the extraction disks used to obtain the sample.

Because of the very low ammonia and organic content and the active ventilation systems on each tank, the generation of flammable vapor mixtures is not possible. Even in the event of a loss of the ventilation system, analytical results to date indicate that the accumulation of flammable vapor mixtures is not possible due to the very low organic content in the waste [32,33]. Thus, these flammable gases do not present an explosion hazard in tank farm facilities.

Metal Nitrides

In 1970, popping noises were heard when personnel stepped on dried waste deposits, when equipment bumped into surfaces contaminated with dried waste, and when a sampling tool was intentionally scraped against dried waste in separate incidents at the Tank $21 \mathrm{H}$ feed-jet enclosure and $242-\mathrm{H}$ evaporator cell. Analysis of a sample of material removed from the inlet feed jumper indicated $92 \%$ mercury and $6 \%$ silver [34]. An investigation of the incident implicated silver nitride as the cause of the explosive deposits [35]. 
An unidentified mercury compound may have also been present and contributed to the shock-sensitivity of the dried material. Attempts to identify a mercury compound proved unsuccessful. Mercury (I) nitride is unknown and mercury (II) nitride proves extremely unstable with an unknown structure. Millon's base, $\mathrm{Hg}_{2} \mathrm{NOH} \cdot 2 \mathrm{H}_{2} \mathrm{O}$, is chemically similar to mercury(II) nitride. The reactivity of Millon's base increases upon drying.

Silver nitride is formed by the decomposition of silver diammine solutions. Since silver and ammonia are known to be present in the waste sent to the evaporator, conditions existed in which silver nitride could have formed. Although the dried waste deposits exhibited an observable reaction, the reaction did not propagate; dried waste deposits adjacent to the waste deposits that were contacted did not undergo observable reaction.

An estimated 55 kilograms of silver transferred into Tank $13 \mathrm{H}$ from the flushing of silver coated Berl saddles located in the H-Area separations canyon during the time period of November 10, 1969 to May 13, 1970 [36]. From Tank 13H, the material transferred into Tank $21 \mathrm{H}$, which was the $1 \mathrm{H}$ evaporator feed tank during this time. A total of 1.95 million gallons of waste transferred into Tank $21 \mathrm{H}$ from Tank $13 \mathrm{H}$ during this period. A total of 2.99 million gallons of waste processed through the evaporator producing 0.83 million gallons of concentrated waste that went into Tank $10 \mathrm{H}$. After cooling, approximately 30,000 gallons of saltcake crystallized. After cooling, the concentrated supernatant liquid transferred from Tank $10 \mathrm{H}$ into Tank $11 \mathrm{H}$, Tank $14 \mathrm{H}$, and Tank $16 \mathrm{H}$ $[37,38]$.

During May and the remainder of 1970 , a concerted effort was made to mix the concentrated silver-containing waste with other waste to dilute the silver content. Multiple waste transfers were made between Tanks $13 \mathrm{H}, 11 \mathrm{H}, 14 \mathrm{H}, 15 \mathrm{H}$, and $16 \mathrm{H}$ to dilute the silver content. During this time an additional 1.9 million gallons of waste, that contained no or only a trace of silver, transferred into the $1 \mathrm{H}$ evaporator system from the Receipt Basin for Offsite Fuels and Tank 12H [37,38]. Also, the saltcake produced between November 1969 and May 1970 was dissolved and mixed with the other concentrated supernatant liquid as described above [39].

Given the volume of waste originally present in the $1 \mathrm{H}$ evaporator system as well as that which was added that contained no or only a trace amount of silver, it is estimated that the silver concentration in the waste was diluted by a factor of two. The introduction of silver into waste tanks was discontinued in 1970. Since this administrative control has been in place, no other incidents of this type have been observed in tank farm operations.

F-Area also received silver containing wastes as a result of flushing the F-Canyon iodine reactors. For the period from July 1956 to October 1970, a total of 310 kilograms of silver transferred into Tank 7F [40]. No incidents of popping noises have ever been reported with waste transferred into this tank or processed through the $2 \mathrm{~F}$ Evaporator. As in the case of the H-Area waste, the silver-containing waste was diluted with other waste that contained no or only a trace amount of silver. Based on waste transfer records the silver was diluted by a factor of 150 with other fresh waste and by a factor of 2 with concentrated waste in the system $[37,38]$. Thus, the concentration of silver in the waste associated with Tank $7 \mathrm{~F}$ and the $2 \mathrm{~F}$ Evaporator system is very low. Over the 29 year 
period since the last silver addition was made, the ammonia has volatilized and any silver nitride that may have formed has hydrolyzed.

Silver-containing waste will be removed and processed for disposal during the ITP and ESP operations. However, the hazard of handling this waste is very low because of the hydrolysis of the silver nitride, the dilution of the silver-containing waste, and the lack of a propagating reaction for the dried waste. Metal nitrides hydrolyze in aqueous solutions producing the metal hydroxide and ammonia [41]. Thius, any silver nitride that may have formed initially has decomposed during the 29 years of storage. During waste removal, any silver-containing waste will be diluted with dissolution water and mixed with other tank waste so that the silver concentration will not be any greater than that sent to the evaporator in 1970. If small amounts of the waste still containing silver nitride were dried and contacted, propagation of the reaction to other waste will not occur based on the behavior exhibited in the 1970 incidents.

\section{Ammonia Compounds and Derivatives}

Ammonium nitrate, ammonium nitrite, and ammonia/air mixtures are well-documented explosive hazards [8]. Impure ammonium nitrate and ammonium nitrite are reported to be much more explosive than chemically pure compounds. The presence of organic material not only increases the sensitivity of the ammonium nitrate to decomposition, but also increases the energy released by reacting with the oxygen present in the air [42].

Ammonium nitrate has been transferred from the chemical separations operations to the waste tanks. The first reported transfer of a large quantity of ammonium nitrate occurred in 1976, when approximately $3100 \mathrm{~kg}$ of ammonium nitrate was discharged to two waste tanks from flushes of the separation canyon vessel vent filters [14]. Because of the low ammonium nitrate and organic carbon content in the waste, the high water content of the waste, and the active ventilation system on the waste tanks, the presence of ammonium nitrate in the waste is not an explosive hazard during storage. For tanks containing dry waste, recent experimental work indicated no evidence of highly exothermic reactions in simulated dry waste materials containing nitrate [11]. The only hazard of the discharge of the ammonium nitrate to the tank farm is the formation of flammable ammonia/air mixtures.

Because of the high $\mathrm{pH}$, the ammonium ion is converted to ammonia. Ammonia is very volatile and is released into the tank vapor space. To prevent the formation of explosive ammonia/air vapor mixtures, transfers of ammonium nitrate into the tank farm were carefully controlled under written procedure [43]. The procedure limited the concentration of ammonium nitrate to $\leq 2.5 \mathrm{wt} \%$ and the quantity of ammonium nitrate that could be received in any twelve-hour period to $\leq 1000$ kilograms. This limit maintained a safe concentration of ammonia in tank vapor space and in the evaporator overheads. During transfers, the vapor space was monitored for ammonia. Transfers were stopped if the ventilation system was lost or if the ammonia concentration exceeded $1.5 \mathrm{vol} \%$, which is an order of magnitude less than the lower explosive limit of $16 \mathrm{vol} \%$ for ammonia/air vapor mixtures [24]. In the event that the tank ventilation system was interrupted, portable generators and blowers were available in each tank farm to restore active ventilation to the tanks in the event that the permanently installed equipment could not be returned to service quickly. 
In 1998, based on a recommendation by Jamison [44], this control was revised in the Tank Farm Waste Acceptance Criteria (WAC). The WAC limits influent transfers of ammonia to $<15 \%$ of the CLFL under liquid-vapor equilibrium [1]. More recently, Swingle and White reevaluated the Tank Farm Waste Acceptance Criteria for ammonia [45]. They recommended that the allowable ammonia concentration be adjusted and tied to limits on sodium and free hydroxide concentrations. The revised ammonia limit will be based on the studies in progress at SRTC [117]. The current limit is implemented to ensure that the ammonia limit is conservative for the influent waste composition. The revised limit will provide a means to establish controls based on influent composition, allowing for more flexible and safe operation.

The evaporation of fresh waste further decreases the ammonia/ammonium ion content of the waste. Ammonium nitrate is more soluble than sodium nitrate in water [46]. Thus, any ammonium ion that is still present in the waste after evaporation will not crystallize but will remain in solution. Upon further storage, the ammonium ion continues to be discharged to the vapor space as ammonia. Thus, the concentration of ammonium/ammonia decreases with storage time and there is no identified mechanism for concentrating ammonium nitrate in tank farm facilities.

The Separations facilities use two other ammonia derivatives, hydrazine and hydroxylamine, as reductants in fuel processing operations. Both compounds are explosive under certain conditions. However, because of the chemical instability of each compound to the conditions present in the fuel separations processes and tank farm handling facilities, neither are present in stored waste.

Hydrazine reacts rapidly with nitrous acid to produce nitrogen, nitrous oxide, and water [14]. This reaction is used in the fuel separations processing operations to destroy excess hydrazine without forming ammonia. Hydrazine is a powerful reductant in basic solutions [47]. Known species in the waste that reacts with hydrazine include nitrate, nitrite, and hydroxide. If insufficient amounts of nitrite were added to destroy the hydrazine during chemical separations, the hydrazine would rapidly react with oxidants or metal ions in solution when the waste is neutralized. Thus, no hydrazine is present in the highly alkaline SRS waste.

Alkaline solutions of hydroxylamine are unstable and decompose to give a mixture of nitrous oxide and ammonia. The rate of reaction is dependent on the concentrations of hydroxide and hydroxylamine and temperature. Because of the high hydroxide concentration and moderate temperatures in the waste tanks, the decomposition of hydroxylamine is fairly rapid. Thus, any hydroxylamine that is discharged to the tank farm will decompose rapidly and will not be present in stored SRS waste. 
Organic Compounds

Organic materials that have been used in chemical processing, and thus, are present in SRS waste include n-paraffin (primarily dodecane), TBP, and ion-exchange resins. Significant quantities of aromatic organic compounds are present in three H-Area tanks as a result of the 1983 demonstration and 1995 startup of the ITP process. The total quantity of aromatic compounds in the H-Area tanks is not increasing due to the suspension of the ITP process in 1998. The total quantity of aromatic compounds in these tanks is decreasing due to radiolytic and chemical decomposition.

High-level waste stored at the SRS contains small amounts of organic compounds. Based on receipts of organic compounds in the tank farms through 1984, a total organic carbon concentration in the waste, assuming a perfect blend, is calculated to be $2200 \mathrm{ppm}$ [48]. The actual concentration is much lower than this due to radiolytic and chemical decomposition. Analysis of two high activity waste receipt tanks indicated a total organic carbon content of $86 \mathrm{ppm}$ and $220 \mathrm{ppm}$ [49]. This is well below the estimate based on organic compound receipts to the tank farm.

Waste composition, waste temperature and active ventilation systems on waste tanks are used to maintain the vapor concentration of the volatile organic compounds below the LFL. Waste generators are prohibited from transferring waste to the Tank Farm containing more than $0.5 \%(\mathrm{v} / \mathrm{v})$ organics. Generators have developed controls as detailed in Waste Compliance Plans to limit the concentration of volatile organics in waste streams sent to the tank farms [2-5]. In addition to limiting the quantity of organics, the Waste Compliance Plans for the F and H-Area Separations Facilities and the DWPF indicate that the facility will not initiate transfers of waste to the tank farms if the waste temperature is above $50^{\circ} \mathrm{C}$. RBOF/RRF waste is very dilute and currently has no external means to heat the waste above ambient temperature. Thus, the waste temperature would not be expected to exceed the maximum seasonal ambient temperature of $38^{\circ} \mathrm{C}$. Limiting the waste temperature to $\leq 50^{\circ} \mathrm{C}$ at the waste generator should maintain waste temperatures in the pump tanks and waste tanks below $70^{\circ} \mathrm{C}$. This temperature is below the reported flash point of $74^{\circ} \mathrm{C}$ for dodecane, the organic diluent having the lowest flash point.

For the organic pump tanks and waste tanks, the active ventilation system keeps the flammable organic concentration below the LFL, just as in the case of hydrogen.

Administrative controls were established to minimize heat introduction into these organic tanks and to maintain ventilation during waste transfer [21, 117]. For non-organic pump tanks and waste tanks, the liquid waste temperature is restricted based on the Tank Farm Technical Safety Requirements [13].

Organic solvent is entrained and dissolved to some extent in the waste streams that enter the tank farm from chemical separations. The organic solvent consists of TBP in organic diluents, which are primarily dodecane. The LFL for dodecane in air is $0.6 \mathrm{vol} \%$. Because of the high volatility of dodecane and similar n-paraffins, these compounds are removed from the waste during storage and evaporation. Based on modeling of the evaporation of organic liquids from waste tanks, the life cycle time of dodecane and $n$ paraffins in SRS waste tanks is only a few months due to the low concentration and active ventilation systems [50]. 
TBP has a low vapor pressure, and thus the concentration in the vapor space is low in SRS waste tanks. Vapor space measurements at SRS have not measured TBP. However, measurements in Tank 241-C-103 at Hanford have indicated that the concentration of TBP in the vapor space is very low, and therefore, TBP does not contribute appreciably to the vapor space flammability [51]. Thus, the discharge of TBP into waste tanks at SRS is not a flammability hazard.

TBP is known to hydrolyze in alkaline solutions producing di-n-butyl phosphate and nbutanol. The flash point of TBP is $\sim 181^{\circ} \mathrm{C}$ [34], which is well above temperatures at which waste is stored or heated during evaporation. During evaporation, the high water content in the evaporator vapor space prevents the accumulation of a flammable vapor mixture during evaporation. n-Butanol has a LFL in air of 1.7\% [24]. Laboratory tests showed that no ignition of the organic material occurs when a salt solution heated to 70 ${ }^{\circ} \mathrm{C}$, containing $530 \mathrm{mg} / \mathrm{L}$ of n-butanol with a layer of TBP on the surface, is contacted with a butane flame [52]. Thus, the discharge of TBP into tank farm facilities is not an explosive hazard.

A tank safety issue at Hanford arose concerning the possible long-term survival of "red oil" material within Hanford waste tanks. If a quantity of a "red oil" material was inadvertently formed in uranium processing operations and subsequently routed to the waste tanks, would this material continue to exist in an energetic form for prolonged periods inside the waste tanks? "Red Oil" is produced when organic materials have been inadvertently allowed to enter vessels containing uranyl nitrate solutions that are heated to relatively high temperatures [53]. The organic materials have been TBP and hydrocarbon diluent and the decomposition products of these materials. A total of three "red oil" incidents have occurred in uranium processing facilities at SRS and Hanford.

Watkin and Gordon conducted an extensive laboratory study investigating the preparation and subsequent stability of "red oil" under the alkaline waste tank conditions [54]. The key finding of their work indicated that "red oil" is not stable under alkaline conditions. Upon contact of the "red oil" with simulated waste solutions for as short as a few minutes, the resulting mixture, after drying, exhibited a differential scanning calorimetry/thermal gravimetric analysis (DSC/TGA) energy of less than $314 \mathrm{~J} \mathrm{~g}^{-1}$. Within the Hanford Tank Safety Program, a dry waste material having a DSC/TGA value of less than $314 \mathrm{~J} \mathrm{~g}^{-1}$ is not considered to pose a threat to interim safe storage within a waste tank. High-level waste at SRS is stored under highly alkaline conditions as is the waste at the Hanford site. Thus, in the unlikely event that "red oil" was produced in the uranium processing facilities at SRS and inadvertently transferred to a waste tank, the material will rapidly decompose upon contact with the alkaline waste and not pose a safety threat to storage within a waste tank.

A potential inadequacy in the safety analysis concerning organic compounds in Tank Farm operations was declared in 1998 [55]. The PISA indicated that the impact of organic compounds on the accident analysis calculations for deflagration in Tank Farm process areas may not be adequate. Specifically, the current controls (organic concentrations, temperature, and ventilation) were established to prevent the formation of flammable vapor concentrations in waste tanks, but not in transfer pump tanks and 
evaporators. Resolution of this issue is in progress. Activities underway include engineering analyses of the impact of organics and implementation of compensatory measures.

As part of the engineering analysis, vapor and liquid samples were recently taken and analyzed from pump tanks and waste tanks that routinely receive fresh waste containing organics. Sampling included Pump Tanks 5-H and 3-F and Waste Tanks 38H, 43H, 26F, $33 \mathrm{~F}$ and $46 \mathrm{~F}$. Vapor samples taken from Pump Tanks 5-H and 3-F exhibited trace amounts of organics that are several orders of magnitude below that which would be a flammability concern [32]. Liquid samples taken at and below the surface of the waste in the waste tanks analyzed to contain low concentrations of organics [32,33]. The concentrations of organics are well below levels that would be a flammability concern. Additional vapor and liquid samples will be taken and analyzed in FY2000. The results of these analyses will be used to complete engineering analyses and determine if existing controls are adequate to ensure safe operations throughout the tank farms.

Slurries produced during the 1983 Demonstration and ITP operations contain tetraphenylborate solids. Laboratory tests have shown that the solids in these slurries are not ignitable due to the high water content (approximately $70 \mathrm{wt} \%$ ) [56,57]. During washing and storage of the ITP slurries, the volume in the processing tanks changes and the solids will adhere to vertical surfaces and dry. Tests have shown that dried deposits are combustible. The combustibility of the solids is dependent on the water content. Fully washed solids (low soluble salt content) are combustible if the water content is less than $20 \mathrm{wt} \%$. Unwashed solids (high soluble content) are combustible only if the water content is less than $10 \mathrm{wt} \%$ [58].

Tanks containing tetraphenylborate solids are purged with nitrogen to reduce the possibility of ignition of tetraphenylborate solids. Recommended operational safety requirements limit the oxygen concentration in these facilities to less than 6.9 vol \% [25]. This reduces the oxygen concentration to a level below that which is required to support combustion. Leak detection equipment has been installed to prevent accumulation of ITP slurries in the tank annulus, the ITP filter cell, transfer lines, and drainage tanks where it could dry and become combustible. Measurement of drying rates of unwashed and washed ITP slurries indicated that the unwashed slurries develop a thin casing that greatly reduced the drying rate [59]. Drying rates for washed slurries are about a factor of four higher than unwashed slurries. If deposits are found, immediate action will be taken to add water and remove the deposits.

Laboratory studies have identified the presence of a number of aromatic compounds, including phenol and nitrated aromatics, in off-gas condensates from several unit operations within the DWPF that are reported to be explosive under certain conditions $[8,9,19]$. Table IV provides a list of the compounds that have been detected. The various off-gas condensates will be combined within the DWPF and recycled to the tank farm after adjusting the $\mathrm{pH}$ of the stream with sodium hydroxide to meet waste acceptance criteria [1]. 
Table IV. Organic Compounds Present in DWPF Off-Gas Condensates [64,65,4]

$\begin{array}{lcc}\text { Compound } & \text { Concentration Range (ppm) } & \text { Explosive[8,9] } \\ \text { aniline } & <1-244 & \text { yes } \\ \text { benzene } & <0.1-10 & \text { yes } \\ \text { biphenyl } & <0.1-10 & \text { no } \\ \text { carbazole } & <0.1-10 & \text { no } \\ \text { 2,4-dinitrophenol } & <0.1-10.6 & \text { yes } \\ \text { diphenylamine } & 1-21.6 & \text { no } \\ \text { diphenyformamide } & <0.1-5.7 & \text { unknown } \\ \text { Dow Corning 544TM } & <0.1-30 & \text { no } \\ \text { ethylene glycol } & <0.1-100 & \text { no } \\ \text { formate } & <0.1-664 & \text { no } \\ \text { nitrobenzene } & <0.1-1 & \text { yes } \\ \text { 2-nitrodiphenylamine } & <0.1-10 & \text { no } \\ \text { 4-nitrodiphenylamine } & <0.1-10 & \text { no } \\ \text { 2-nitrophenol } & <0.1-800 & \text { yes } \\ \text { 4-nitrophenol } & <0.1-580 & \text { yes } \\ \text { 4-nitrosophenol } & <0.1-1400 & \text { yes } \\ \text { phenol } & <2-2800 & \text { yes } \\ \text { 3H-phenoxazin-3-one } & <0.1-5 & \text { unknown } \\ \text { 4-phenylazophenol } & <0.1-64 & \text { unknown } \\ \text { N-phenylformamide } & <0.1-10 & \text { unknown } \\ \text { 2-phenylphenol } & <1-54 & \text { unknown } \\ \text { 4-phenylphenol } & <1-11 & \text { unknown } \\ \text { quinone } & <0.1-10 & \text { no } \\ \text { sodium formate } & 0-870 & \text { no } \\ \text { Surfynol } & <0.1-100 & \text { no } \\ \text { m-terphenyl } 104 & <0.1-41 & \text { no } \\ \text { o-terphenyl } & <0.1-10 & \text { no } \\ \text { p-terphenyl } & <0.1-10 & \text { unknown } \\ \text { triphenylamine } & & \end{array}$

Based on a review of the reported literature, phenol (phenoxide in high pH solutions) is relatively stable [60]. A potentially hazardous rapid exothermic reaction was reported upon the addition of an acidic sodium nitrate solution to phenol [8]. High-level waste contains high concentrations of nitrate, but is strongly alkaline. Thus, an exothermic reaction between phenoxide and the alkaline waste will not occur upon introduction of the DWPF Recycle Stream to the tank farm. Experimental studies determined the fate and impact of the introduction of phenol/phenoxide into tank farm operations to ensure there are no exothermic reactions between phenol /phenoxide or the radiolytic decomposition products of phenol/phenoxide and other waste components [61-63].

Under alkaline conditions, the nitrated aromatics convert to the respective sodium salts, which are also explosive [8]. The sensitivity of the nitrated aromatics increases with temperature. Thus, there is a risk that violent decomposition reactions may occur upon 
heating the DWPF Recycle stream containing nitrated aromatics with the strongly alkaline tank waste (e.g., during evaporation).

Specific operations and factors investigated included caustic adjustment, addition to Tank $43 \mathrm{H}$, evaporation, and radiolysis of evaporator feed solutions and products. Barnes concluded from this experimental program that the introduction of the organic compounds in the DWPF recycle stream should not adversely impact the safety of tank farm facilities. Key results and findings of the prograim included the following [63].

- No exothermic reactions were observed, due to thermal decomposition, within the operating temperature range of the tank farm waste tanks and evaporators.

- No increase in the concentration of 2,4-dinitrophenol was observed in any of the tests. This indicates further nitration of mono-nitrophenols is not occurring.

- No significant changes were observed in either the exothermic behavior or concentration of nitrophenolics in materials used during radiolysis testing at doses up to $2.4 \times 10^{7}$ Rads.

- With respect to both exothermic behavior and the respective concentration of nitrophenolics, no noticeable changes were identified between simulants with and without mercury.

- With the exception of a minute volume of solid deposits in the Hot Wall apparatus, no significant deviations in characterizations were observed between Hot Wall test material and laboratory evaporator test material. The deposits obtained from Hot Wall testing showed no exothermic behavior at temperatures to $400^{\circ} \mathrm{C}$ and were composed largely of sodium, silicon and aluminum.

- No black solids or tar-like mixtures were formed during evaporator, Hot Wall or any other tests.

- A review of the literature indicated no examples for the catalysis of aromatic nitration reactions under alkaline conditions.

\section{CLASSES THAT ARE NOT A HAZARD}

\section{Metal Fulminates}

Silver and mercury fulminates are commonly prepared by the addition of acidic silver or mercury nitrate solutions to an alcohol and allowing the mixture to stand [66]. A mixture of mercuric oxide and mercury fulminate reportedly forms when a solution of mercuric chloride in ether is added to an ice-cold solution of monochloroformoxime in sodium hydroxide [120]. Formation of metal fulminates by either of these methods appears unfavorable in tank farm operations due to the waste composition and environmental conditions.

Acidic solutions of mercury and silver are unlikely due to the controls in place to make all waste alkaline prior to transfer into the tank farms. Alcohol concentrations are also very low in HLW. Monochloroformoxime or its precursor, monochloroformaldehyde are not used on site. Although, formate and chloride are present in HLW, monochloroformaldehyde would not form from these species under tank farm conditions 
[121]. Oximes form by the reaction of ketones or aldehydes and hydroxlamines with the elimination of water. In the event that both reagents would be present, the high water content of the waste would retard the formation of the oxime. Thus, the chemistry present in tank farm operations is very unfavorable for the formation of metal fulminates.

During the investigation of an incident in 1970, metal fulminates were identified as possibly being formed. Laboratory tests were conducted to determine if silver and mercury fulminates are prepared under conditions present in the waste tanks. The tests indicated that fulminates are not produced at the conditions existing in the waste tanks [35].

Since 1970, the introduction of silver into the tank farm from the flushing of silver-coated Berl saddles has been stopped. Mercury is used in Separations processing as a catalyst for the dissolution of aluminum. Most of the mercury is precipitated upon neutralization of the high-level waste. However, some of the mercury is soluble at the high $\mathrm{pH}$. Therefore, a fraction of the mercury entering the tank farm will be present in the solutions transferred to salt processing. The bounding concentrations of silver and mercury in the salt solution are estimated at $1.0 \mathrm{~g} / \mathrm{L}$ and $0.5 \mathrm{~g} / \mathrm{L}$, respectively [67]. The average concentrations are $0.0005 \mathrm{~g} / \mathrm{L}$ for $\mathrm{Ag}$ and $0.0004 \mathrm{~g} / \mathrm{L}$ for $\mathrm{Hg}$ assuming a perfect blend of all F-Area and H-Area wastes.

Alcohols have not been used as process chemicals at SRS and are only present in trace amounts as a result of laboratory operations and decomposition of tri-n-butyl phosphate and other organics. Methanol and isopropanol are two impurities which will be present in the monosodium titanate (MST) slurry that was used in the ITP process and expected to be used in the alternate salt process. To reduce the quantity of alcohol that is introduced into the tank farm, the maximum amount of alcohol in the MST slurry is limited to 3\% by volume [68]. MST slurries, prepared and submitted to WSRC by vendors, have been analyzed to contain $<0.1 \%$ by volume alcohols.

Assuming the alcohol concentration of the MST slurry is $3 \%$ by volume, calculation indicate the maximum possible alcohol concentration in the ITP precipitation tank at $160 \mathrm{ppm}$ [69]. The concentration of alcohol will be further reduced upon filtering and washing of the slurry in subsequent processing steps. Also, some of the alcohol will be removed from the decontaminated supernate during benzene stripping. Because of the very low concentration of alcohol and the relatively low concentrations of silver and mercury, the formation of silver and mercury fulminates is extremely unfavorable in tank farm facilities.

Although the formation of mercury fulminate is extremely unlikely in HLW, evaluation of energetic reactions in dry sludge included this compound to serve as a standard for possible energetic mercury compounds [11]. Impact testing with simulated sludges containing up to $21.5 \mathrm{wt} \%$ mercury fulminate exhibited no signs of reaction or shock sensitivity. Calorimetry measurements of the mixtures exhibited a low-energy exothermic reaction of roughly the same magnitude as pure mercury fulminate. The addition of organic materials did not alter the calorimetry measurements. 
Kaufman reported that mercury fulminate decomposes when irradiated in a gamma field [70]. Fondeur and Wilmarth recently reported that mercury fulminate transforms into a less energetic form upon irradiation in a gamma source, and completely decomposes rapidly when contacted with $1 \mathrm{M}$ sodium hydroxide and irradiated in a gamma source $[71,112]$. Silver and other metal fulminates would be expected to behave similarly [70]. In the unlikely event that metal fulminates transferred into or were produced in the waste tanks, the combination of high alkalinity and high radiation field in the waste tanks will decompose the metal fulminates into less energetic materials. Thus metal fulminates cannot accumulate and, therefore, are not an explosion hazard in tank farm facilities.

\section{Metal Azides}

Hydrazoic acid, $\mathrm{HN}_{3}$, is reported to be dangerously explosive [8]. The minimum explosive concentration of $\mathrm{HN}_{3}$ is reported to be $4.7 \mathrm{M}(17 \mathrm{wt} \%)$ in aqueous solutions. Heavy metal azides such as silver, mercury, lead, cadmium, and barium are also reported to be explosive and have been used in detonation assemblies [72]. Electropositive metal azides such as sodium azide are not explosive, and decompose smoothly at temperatures above $300^{\circ} \mathrm{C}[47]$.

Azide ion is reported to react with nitrite to produce nitrous oxide and nitrogen as given in equation 1 [73]. Reaction rates have not been reported under alkaline conditions. Because of the high nitrite concentration in high-level nuclear waste and the low solubility of heavy metals at high $\mathrm{pH}$, there is no conceivable mechanism by which hydrazoic acid and/or metal azides are produced during storage or during DWPF feed preparation processes. As a result, the formation of explosive azides is not a significant hazard in tank farm operations.

$$
4 \mathrm{~N}_{3}^{-}+2 \mathrm{NO}_{2}^{-}=4 \mathrm{~N}_{2} \mathrm{O}+3 \mathrm{~N}_{2}
$$

Hydrazoic acid is known to be one of the products from the reaction of hydrazine with nitrite in nitric acid solutions [74]. From a consideration of the accumulation of explosive solutions by distillation or the formation of explosive mixtures of hydrazoic acid in air by vaporization, it was established that a concentration of $0.05 \mathrm{M}$ hydrazoic acid in process solutions is a safe limit for the Separations canyons [74]. Based on laboratory studies and actual measurements of process solutions, the maximum concentration of hydrozic acid in unneutralized waste solutions is $0.012 \mathrm{M}$ [74].

Each of the 1970 incidents associated with dried waste deposits in the Tank $21 \mathrm{H}$ feed jet enclosure (see Metal Nitrides section) occurred shortly after flushing of silver-coated Berl saddles in Separations operations. Mercury and silver fulminates were eliminated as the cause when attempts to prepare either compound were not successful in the laboratory [35]. Mercury and silver azides were ruled out as possible candidates because of the instability of these compounds in high radiation fields [20].

Metal azides are possibly produced during Separations processing. Mercuric ion is the only heavy metal ion present in significant quantities during the generation of hydrazoic acid. Thus, mercuric azide is the only metal nitride that deemed possible as forming at this stage. Evans, et. al. reported that explosive or spontaneous detonating mercury azide 
is formed only under conditions of slow diffusional growth [75]. Laboratory tests indicated no spontaneous detonations in aqueous mercuric solutions containing less than $0.02 \mathrm{M}$ azide [35]. In tests with both ferric and mercuric ions present (which more accurately represent actual process conditions), the precipitated solids were not detonated at mercury concentrations up to $0.08 \mathrm{M}$ and azide concentrations up to $0.16 \mathrm{M}$. These concentrations greatly exceed the concentrations of mercury and azide in neutralized stored waste.

\section{Metal NO Compounds}

Reported explosive compounds of this type include the anhydrous form and salts of Millon's base, lead hyponitrite, silver hyponitrite, and nitrate salts. Sodium nitrate is a strong oxidant. Impregnation of cellulosic materials (e.g., wood and paper) with sodium nitrate increases the combustibility [8] of the cellulosic materials.

The only identified source of cellulosic materials into tank farm facilities is that present in the Antifoam B Emulsion (1-5\% methylcellulose) used to minimize foaming in HLW evaporators. The quantity of methylcellulose added to the waste is very small. Records indicate no more than $320 \mathrm{~kg}$ of methylcellulose was added during FY99 [76].

No incidents of uncontrolled reactions have been reported during evaporator operations and laboratory evaluations using this defoamer [47]. The high water content and low oxidizing power of nitrate under alkaline conditions prevent rapid reaction between the nitrate and the methylcellulose. Nitration of cellulose occurs only under strongly acidic conditions and elevated temperatures $\left(>160^{\circ} \mathrm{C}\right)[8,9]$. Cellulosic materials will decompose during storage due to radiolysis and alkaline hydrolysis [78]. Consequently, the small amount of methylcellulose added to the waste from Antifoam B Emulsion use will not accumulate in tank farm facilities and does not present an explosion hazard.

Hyponitrite forms by reacting hydroxylamine with nitrite and the reduction of nitrite by sodium amalgam [47]. Sodium amalgam and hydroxylamine are not present in SRS waste, and therefore, hyponitrites are not prepared by these reactions in SRS waste tanks. However, nitrate is reduced by radiolysis to nitrite, and thus, lower oxidation state nitrogen-oxygen compounds such as hyponitrite may be produced radiolytically. Mercury, lead, and silver are all present in SRS waste, and thus, hyponitrite salts with these metals are conceivable.

Lead and mercuric hyponitrite are reported to decompose in the presence of sodium hydroxide. Because of the high hydroxide concentration in SRS waste, both of these compounds are not stable and sufficient quantities do not exist to present a hazard. The introduction of silver-containing waste into the tank farms was stopped in 1970. As a result, the concentration of silver in SRS waste is very low and is not concentrated by the ITP or ESP operations. Thus, the formation of silver hyponitrite is very unlikely.

Millon's base, $\mathrm{Hg}_{2} \mathrm{NOH} \cdot 2 \mathrm{H}_{2} \mathrm{O}$, may exist in high-level waste, but is not an explosive compound. The monohydrate is feebly explosive and the anhydrous compound, $\mathrm{Hg}_{2} \mathrm{NOH}$, is explosive. The monohydrate and anhydrous compound are generally 
prepared by dehydrating Millon's base in an atmosphere of anhydrous ammonia or by heating in the presence of desiccants.

In 1988, shock-sensitive deposits were detected on laboratory corrosion test specimens immersed in solutions simulating the DWPF off-gas condensate stream, which will be recycled to the $\mathrm{H}$-Area tank farm. This stream is a relatively dilute aqueous solution containing nitrate, mercury, phenoxide, and halides. Nitrite and hydroxide will be added to the waste stream to inhibit against possible pitting corrosion of the carbon steel waste tanks.

Conclusive identification of the compound was not possible due to the small quantity of material isolated: Based on the analytical results obtained, the deposits contained mercury and nitrogen. The solid deposits may be a salt of Millon's base or some other mercury $\mathrm{NO}_{\mathrm{x}}$ compound [79].

From 1991 to 1993 , three separate laboratory studies were carried out to reproduce the formation of the shock-sensitive deposits [80-82]. Test conditions were also expanded to bound conditions that will occur in the waste storage tanks. These tests included steel with mill-scale representing the primary tank vessel, addition of ammonia, and variations in waste composition to reflect changes in the DWPF flowsheet.

Deposits and films were observed in some of the tests. However, none of the deposits or films exhibited shock-sensitive properties as observed in 1988. Since the latter tests showed no evidence of shock-sensitive deposits, it was concluded that the deposits found in 1988 were the result of impurities in the reagent chemicals and that the production of shock-sensitive deposits is extremely unlikely to occur upon introduction of the DWPF Recycle Stream into the tank farm [83].

\section{Halogen Compounds}

Chloride is present in the high-level waste as an impurity in the sodium hydroxide used to neutralize acidic waste before introduction into the carbon steel waste storage tanks. Typical waste from standard Separation processes contains about $0.05 \mathrm{~g} / \mathrm{L}$ of chloride. Two tanks have received waste containing higher levels of chloride. Tank $5 \mathrm{~F}$ received about $250 \mathrm{~kg}$ of chloride $\left(\left[\mathrm{Cl}^{-}\right]=0.095 \mathrm{~g} / \mathrm{L}\right)$ and Tank $8 \mathrm{~F}$ received about $2300 \mathrm{~kg}$ of chloride $\left(\left[\mathrm{Cl}^{-}\right]=0.9 \mathrm{~g} / \mathrm{L}\right)$ from a special curium processing operation at the Savannah River Laboratory [84]. The high chloride waste was mixed with other plant waste and sent to these tanks. Supernatant liquids from both of these tanks were subsequently concentrated by evaporation and the concentrate transferred to salt receiving tanks in FArea following normal waste management practices.

Iodine is a fission product present in the spent fuel. Most of the iodine is removed by scrubbing the off-gases from fuel dissolution with silver impregnated Berl saddles (iodine reactors). The silver iodide is removed from the saddles with acid flushes. The acid solutions are then made alkaline with sodium hydroxide and sent to the tank farm. A small amount of the fission-product iodine is reduced to iodide and travels through fuel processing operations and is received into the tank farm with standard waste. Transfers of flushes from the iodine reactors to the tank farm were stopped in 1970 (see Metal 
Nitride section). Thus, only small amounts of iodide have been added to the waste since 1970 .

Halo-nitrogen compounds such as nitrogen triiodide and nitrogen trichloride and halooxygen compounds such as chlorine dioxide and dichlorine heptaoxide are known to be explosive under certain conditions [8,9]. All of the necessary elements are present in SRS for each of these compounds. However, the conditions necessary to produce these compounds are not present in the SRS chemical separations and waste handling facilities. Also, these compounds are not stable in highly alkaline aqueous solutions. Nitrogen triiodide is reported to decompose upon exposure to ionizing radiation [20]. Consequently, conditions within tank farm facilities prevent the production or accumulation of these compounds in sufficiently large enough quantities to be an explosion hazard.

Nitrogen trichloride and nitrogen triiodide are formed by reacting the ammonium halide with the appropriate hypohalous acid or halogen gas [85]. Traces of hypohalous acid or halogen may be present during chemical separations, and thus, these compounds may be formed in the separations canyon. However, under alkaline conditions, neither hypohalous acid or halogen gas are present in tank farm operations. Nitrogen trichloride and nitrogen triiodide are readily hydrolyzed in alkaline solution to reform ammonium halide and nitrogen. Since SRS waste contains a high water content, any nitrogen halide formed during separations processing is hydrolyzed to non-explosive compounds.

Chlorine dioxide can be produced by one of four reactions: (1) disproportionation of chloric acid, (2) oxidation of chlorite with chlorine, (3) reduction of chlorate with oxalic acid, and (4) reaction of chloride and chlorate in acid [85]. Since chlorine and acid conditions do not exist during waste processing and storage operations, chlorine dioxide is not generated. During cleaning of a waste tank with oxalic acid, there exists the possibility of generating chlorine oxide if chlorate were present. Chlorate is not a process chemical, but conceivably produced by the oxidation of chloride. However, from the enthalpy of formation, the concentration of chlorate in the highly alkaline waste based on the bounding chloride concentration is calculated to be no more than $3.1 \times 10^{-29} \mathrm{M}$. Thus, the amount of chlorine dioxide that is produced is extremely small and is not an explosion hazard.

Dichlorine heptaoxide is produced by the dehydration of perchloric acid. Perchlorates are not used as process chemicals at SRS and the formation of appreciable amounts of perchlorates is not possible based on thermodynamics (see Metal Oxohalogenates). Since the waste is stored as highly alkaline aqueous slurry, dehydration of perchloric acid, if present, is highly unlikely.

Metal-Amine Complexes

Amine complexes of metals containing oxyanion ligands have been reported to be explosive and exhibit moderate to strong shock sensitivity. These compounds are particularly hazardous because of the presence of both fuel (amine) and oxidant (oxyanion ligand) in the same compound. SRS waste contains all three species for forming complexes of this type: ammonia, metal ions, and oxyanions (e.g. nitrate, nitrite, 
and sulfate). Metals ions that are present in SRS waste and conceivably form amine complexes include copper, chromium, cobalt, mercury, palladium, silver, and zinc.

The chemistry existing in SRS tank farm operations is extremely unfavorable for the formation of these complexes. Also, any metal amine complexes that might be introduced into the tank farm rapidly decompose because of the high $\mathrm{pH}$ and produce non-explosive compounds. Thus, metal amine complexes are not an explosion hazard in SRS waste tank farm facilities.

Preparation of metal-amine complexes is generally carried out in concentrated ammonium hydroxide solution or liquid ammonia. Syntheses of metal amine complexes have also been reported in which metal salts are treated with ammonia gas at elevated temperature [86]. None of these conditions exist in any tank farm facility or operation.

Metal-amine complexes are known to hydrolyze in aqueous solutions. The reactivity of a particular complex varies for different metals and the specific chemical conditions (e.g concentration, $\mathrm{pH}$ and temperature) [87]. At the $\mathrm{pH}$ that is maintained in the waste tanks $(\mathrm{pH}>12)$, the metal-amine complexes rapidly hydrolyze to metal hydroxide and hydrous metal oxide species. Thus, metal-amine complexes are not present in sufficient quantities in SRS wastes to present an explosion hazard.

\section{Nitrate/Oxalate Mixtures}

Based on the heats of formation, the reaction of sodium nitrate and sodium oxalate is extremely exothermic and would generate large amounts of gas that could exceed the capacity of the HEPA filters on the waste tanks. From the chemical reaction below (equation 2), the heat of reaction is

$$
2 \mathrm{NaNO}_{3}+5 \mathrm{Na}_{2} \mathrm{C}_{2} \mathrm{O}_{4}=6 \mathrm{Na}_{2} \mathrm{CO}_{3}+4 \mathrm{CO}_{2}+\mathrm{N}_{2}
$$

calculated to be $-203.4 \mathrm{kcal} / \mathrm{mole}$. No references to explosive hazards of mixtures of sodium nitrate and sodium oxalate have been found in the literature. Differential thermal analyses of mixtures of sodium nitrate, sodium nitrite, and sodium oxalate indicate that both endothermic and exothermic reactions initiate upon heating about $150^{\circ} \mathrm{C}$. Endothermic reactions initiate from about $160^{\circ} \mathrm{C}$ to $315^{\circ} \mathrm{C}$. A single exothermic reaction is initiated in the range from $375^{\circ} \mathrm{C}$ to $450{ }^{\circ} \mathrm{C}[8,11]$. The observed reactions appeared well behaved.

Since SRS waste is typically evaporated, stored, and processed at temperatures of $\leq 155$ ${ }^{\circ} \mathrm{C}$, which is well below the temperatures necessary to initiate exothermic reactions, exothermic reactions of sodium nitrate and oxalate are very unlikely during typical storage and processing operations. The waste in Tank $1 \mathrm{~F}$ experienced a much higher temperature, $340{ }^{\circ} \mathrm{C}$ [89]. This temperature is still below that reported for an exothermic reaction to occur. Thus, SRS waste mixtures containing sodium nitrate and sodium oxalate together are not a hazard under existing and past operating conditions. 
Metal Oxalates

During sludge removal from Tank 16, a special procedure using oxalic acid assisted in slurrying the final $15 \%$ of sludge. Under acid conditions, mercury and silver oxides can react with oxalic acid to produce insoluble mercury and silver oxalates [90]. Silver and mercury oxalates are reported to be weakly explosive, and therefore, an experimental study was undertaken to determine the explosive hazards of this procedure.

Based on the amount of mercury in the waste, a calculation estimated the maximum amount of mercury oxalate - in the waste tank at $900 \mathrm{~kg}$. The concentration of silver was not known, but based on analysis of similar waste in other tanks, the amount of silver was far less, and thus, the amount of silver oxalate in this tank was insignificant compared to the mercury oxalate. For other waste tanks, the amount of silver may be significantly higher, and therefore, the amount of silver oxalate may be significant.

Experimental testing indicated that neither compound ignites by an electric arc when dispersed in air [90]. Explosions well below detonation conditions occurred only when the materials were confined or dry and in a pure form. There is no conceivable mechanism by which pure compounds are produced in the tank farm facilities. However, dry metal oxalates may be present in the dry sludge tanks. Thus, mercury oxalate was selected as one of the standard materials for testing the reactivity of dry sludge [91]. Impact tests indicated that mixtures of simulated sludge containing as much as $14.9 \mathrm{wt} \%$ mercury oxalate exhibited no visible signs of reaction. Calorimetry measurements of the same mixtures exhibited no net exothermic behavior since mercury oxalate decomposition occurs at a temperature overlapping a region of endothermic behavior for the pure sludge [11].

Testing also indicated that both mercury and silver oxalates undergo metathesis reactions under alkaline conditions to give the insoluble metal hydroxides [90]. Fondeur and Wilmarth recently reported that mercury oxalate decomposes upon contact with $1.0 \mathrm{M}$ sodium hydroxide or upon irradiation at a gamma dose of 9.5 Mrad [71]. Silver oxalate was not tested, but would be expected to react similarly. Thus, mercury and silver oxalates will not accumulate in tank farm facilities and present an explosion hazard.

\section{Metal Halogenates}

Of all halogenates, iodate would be the most thermodynamically favored species [47]. Assuming an iodide concentration of $2.1 \times 10^{-6} \mathrm{M}$ [92] and an oxygen concentration of $0.01708 \mathrm{~mL} / \mathrm{mL}$ of solution [93], the equilibrium concentration for iodate is $1.1 \times 10^{-11} \mathrm{M}$. This concentration is equivalent to about $10 \mathrm{mg}$ of iodate in a waste tank completely filled with supernate. The concentration of chlorate is calculated to be no more than $3.1 \mathrm{x}$ $10^{-29} \mathrm{M}$ (see Halogen section). Because of the extremely small amounts of halogenates that are calculated to be present in liquid waste, this class of compounds is not an explosion hazard in SRS tank farm facilities.

Metal Cyanides/Cyanates

The compounds in this class are often endothermic and can undergo violent oxidation at elevated temperatures and release significant amounts of energy. Literature reports indicate mixtures of solid potassium and mercury(II) cyanides and sodium nitrite explode when heated [8,9]. Mercury cyanate explodes when crushed and endothermic 
compounds such as cadmium cyanide and nickel cyanide decompose explosively under certain conditions.

Potassium, nickel, and mercury are known components of SRS high level waste. However, based on the absence of an identifiable source of significant amounts of cyanide and cyanate and the instability of both species to the physical and chemical conditions at which waste is stored and processed in the tank farms, the accumulation of metal cyanides and metal cyanates in quantities that would be sufficient to be an explosion hazard is unlikely.

Cyanide and cyanate compounds have not been used in processes at the SRS, although very small amounts of cyanide and cyanate may have been introduced in the waste from use at site laboratories or as impurities in process chemicals. Acetonitrile is used in the DWPF analytical laboratory. Estimates indicate that $23 \mathrm{~kg}$ of acetonitrile will be discarded to lab wastes each month [94]. This waste will be routed to the DWPF Recycle Collection Tank (RCT). Normally, the $\mathrm{pH}$ of this tank is very low, and thus, the acetonitrile will undergo hydrolysis producing acetic acid and ammonia [95]. Prior to transfer of the DWPF Recycle Stream to Tank $43 \mathrm{H}$, the waste in the RCT is made strongly alkaline by addition of concentrated sodium hydroxide solution. Organic nitriles also undergo hydrolysis under alkaline conditions [96]. Thus, any unreacted acetonitrile is hydrolyzed in the strongly alkaline conditions. Therefore, the release of acetonitrile from the DWPF laboratory will not provide a source of large quantities of cyanide in the tank farm for the formation and accumulation of metal cyanide compounds.

Cyanides oxidize easily to cyanates in solution [97] and decompose in the presence of ionizing radiation $[20,98,99]$. Cyanide has not been detected in SRS high-level waste, although in 1986, analysis of a Tank $50 \mathrm{H}$ sample indicated a cyanide concentration of 3.6 ppm [100]. Review of the sample analysis indicated that the positive result for cyanide in this sample was an artifact of the experimental procedure. Analytical results for all other Tank $50 \mathrm{H}$ samples indicated no evidence of cyanide.

Cyanates undergo radiolytic decomposition [101] and hydrolysis in strongly alkaline solutions [102]. Hydrolysis of cyanate produces carbonate, carbon dioxide, and ammonia. Based on the absence of an identified source of significant amounts of cyanide and cyanate and the instability of both species to the physical and chemical conditions at which waste is stored and processed in the tank farms, metal cyanides and metal cyanates are not an explosion hazard is SRS tank farm facilities.

\section{Peroxides}

There are three possible types of peroxide explosion hazards: (1) peroxide/organic mixtures, (2) organic peroxides, and (3) metal peroxides. Hydrogen peroxide/organic mixtures explode when the ratio of peroxide to water is $>1$ and the overall fuel/peroxide composition is close to the stoichiometric value. Metal peroxides explode when heated above $100^{\circ} \mathrm{C}$. Metal peroxides that may conceivably be present in the waste are those of silver, barium, calcium, cadmium, mercury, potassium, sodium, strontium, and zinc.

Hydrogen peroxide is not used at SRS in chemical processing operations. Very small amounts of peroxide may have been added to the tank farm from use at SRTC. 
Radiolytic generation of peroxide is well known in aqueous solutions [103]. The radiolytic generation rate for peroxide varies slightly with $\mathrm{pH}$, decreasing slightly in alkaline solutions as compared to acidic solutions.

Hydroxyl radical scavengers such as chloride, bromide, iodide, and nitrite decrease the rate for peroxide formation. Since nitrite and chloride are present in relatively high concentration, the waste suppresses the formation of peroxide. Consequently, there is no plausible mechanism by which peroxide concentration would begin to approach that of water present in the waste. Thus, the possibility of forming an explosive peroxide/organic mixture is unlikely.

Because of the low organic content of the waste and the instability of organic peroxides in highly alkaline solutions, organic peroxides do not present a safety hazard in tank farm operations. Organic peroxides are conceivably produced in waste by the reaction of organics with oxygen-containing radicals or the combination of two alkoxide radicals. These types of radicals are well known products produced by the radiolysis of water and alcohol solutions. However, the concentration of organics in the waste is very low and as a result, the concentration of organic peroxides generated by either of these pathways is also very low.

Conceivable examples of organic peroxides include performic acid and peracetic acid or their respective sodium salts. Both of these peroxides are very reactive $[9,24]$. The literature indicates peracetic acid explodes when heated to $105^{\circ} \mathrm{C}$ [9]. One of the preferred methods for the disposal of organic peroxides is to treat the peroxide with sodium hydroxide solution $[87,104]$. Because of the storage conditions (temperature and high hydroxide concentration) in SRS waste, organic peroxides are not stable, and the accumulation of hazardous quantities of organic peroxide is not possible.

The chemical and physical conditions for the storage and processing of HLW limits the accumulation of metal peroxides in quantities that would be sufficient to be an explosion hazard [105]. Heavy metal peroxides (e.g., $\mathrm{Ag}, \mathrm{Cd}, \mathrm{Hg}$, and $\mathrm{Zn}$ ) are not stable in water. Because of the high water content of SRS waste, the heavy metal peroxides are not stable and significant quantities are not produced. Potassium peroxide requires cold temperatures $\left(<10^{\circ} \mathrm{C}\right)$ to remain stable in aqueous solutions. Since SRS waste storage conditions are at higher temperatures $\left(>30^{\circ} \mathrm{C}\right)$, potassium peroxide would immediately decompose.

The alkaline earth peroxides (e.g., $\mathrm{Ca}, \mathrm{Sr}$, and $\mathrm{Ba}$ ) are reported to react with sodium carbonates and sulfates precipitating the alkaline earth carbonate or sulfate and liberating oxygen. Since appreciable quantities of carbonate and sulfate are present in SRS waste, any alkaline earth peroxides that might be formed immediately react with carbonate or sulfate. Sodium peroxide is fairly stable in aqueous solutions and will crystallize from aqueous solution. However, transition metal ions (e.g., $\mathrm{Fe}, \mathrm{Mn}, \mathrm{Cu}, \mathrm{Co}$, and $\mathrm{Ni}$ ) are known to catalyze the decomposition of sodium peroxide. Since all of these metals are known to be present in SRS waste, it is unlikely that appreciable quantities of sodium peroxide form and crystallize from waste stored in the tank farms. 


\section{Metal Acetylides}

DWPF uses Surfynol ${ }^{\circledast} 104 \mathrm{E}$ and ITP recommended the use of Surfynol ${ }^{\circledR} 420$ to control foaming in the Late Wash facility. Surfynol ${ }^{\circledR} 420$ was not used in the ITP process prior to halting ITP operations in 1998 . Thus, the only source of Surfynol ${ }^{\circledR} 104 \mathrm{E}$ in tank farm facilities is currently from the receipt of the DWPF recycle stream. Currently, these facilitiès include Tank $43 \mathrm{H}$, Tank $38 \mathrm{H}$, Tank $22 \mathrm{H}$, Tank $21 \mathrm{H}$ and the $2-\mathrm{H}$ Evaporator.

The active ingredient in Surfynol ${ }^{\circledR} 104 \mathrm{E}$ is an acetylenic glycol, 2,4,7,9-tetramethyl-5decyne-4,7-diol dissolved in ethylene glycol. Surfynol ${ }^{\circledR} 420$ is an ethylene oxide adduct of 2,4,7,9-tetramethyl-5-decyne-4,7-diol in ethylene glycol.

Copper, silver and mercury acetylides are known explosives [8,9]. Decomposition of the acetylenic glycol could produce an acetylide. Since copper, silver and mercury are present in SRS HLW, the formation of explosive metal acetylides is conceivable. Based on a review of the formation and reaction chemistry of metal acetylides, Hobbs concluded that conditions in the tank farm prohibit the accumulation of metal acetylides in sufficient quantity to be an explosion hazard [106].

Acetylene and terminal alkynes react with metal ions in solid/vapor reaction or in nonaqueous solvents to produce metal acetylides. If a terminal hydrogen atom is not present, no reaction occurs. The acetylenic glycol in Surfynol ${ }^{\circledR} 104 \mathrm{E}$ does not have a terminal hydrogen and, therefore, will not react directly with metal ions to produce metal acetylides. Radiolytic and chemical decomposition of the acetylenic glycol could produce acetylene, other terminal alkynes, methyl isobutyl ketone and low molecular weight alcohols $[28,29]$.

Metal acetylides react with water to produce the alkyne and the corresponding metal hydroxide. The high water content in the waste prevents the accumulation of metal acetylides in the bulk of the waste. Solids adhering to the tank wall may have sufficiently low water content so that the metal acetylide could form and not undergo hydrolysis immediately. However, those tanks in which Surfynol ${ }^{\circledR}$ defoamers would enter are not static tanks and frequently change in volume resulting in wetting and decomposition of any metal acetylide that formed in the solids. Thus, there is no identified mechanism for the formation and accumulation of metal acetylides and, therefore, this class of explosive compounds is not a hazard in tank farm facilities.

\section{ACKNOWLEDGMENTS}

The author would like to thank G. K. Georgeton, P. D. d'Entremont and T. E. Britt for their assistance in locating much of the data concerning waste tank transfers and practices. The author also thanks R. F. Swingle, D. D. Walker, J. R. Fowler, M. J. Barnes, C. W. Hsu, D. G. Karraker, and M. C. Thompson for many helpful discussions and information. 


\section{REFERENCES}

1. C. I. Aponte, "Waste Acceptance Criteria for High Level Waste Transfers to the 241F/H Tank Farms (U)," X-SD-G-00001, Revision 3, December 1998.

2. J. E. Batton, Jr., "Waste Compliance Program for Liquid Waste Transfers from FArea Canyon to 241-F Tank Farm, NMS-ETS-95-0044, Revision 2, November 30, 1998.

3. T. M. Fleck, "Waste Compliance Program for Liquid Waste Transfers from H-Area Canyon to 241-H Tank Farm," NMS-EHA-970493, Revision 2, March, 1999.

4. J. M. Gillam, "Waste Compliance Plan for Radioactive Liquid Waste Transfers from DWPF to 241-H Tank Farm," X-SD-G-00005, Revision 1, May, 1999.

5. B. L. Westover, Waste Compliance Program for Liquid Waste Tansfers from RBOF/RRF to 241-H Tank Farm," WSRC-TR-95-0379, Revision 2, March 10, 1999.

6. "High Level Waste Engineering Monthly Data Report (U)," WSRC-RP-94-383-11, November 1994.

7. S. Hall, "Evaluation of Waste Tanks Containing Dry Sludge," NI-HLW-96-018, Rev. 4, March 30, 1999.

8. L. Bretherick, Handbook of Reactive Chemical Hazards, Fourth Edition, Butterworths, London, 1990.

9. Encyclopedia of Explosives and Related Items, U.S. Army Research and Development Command, TACOM, ARDEC, Picatinny Aresenal, New Jersey, USA, Volumes $1-10$.

10. R. F. Swingle, "Task Technical and Quality Assurance Plan for Characterization of Dry Sludge," WSRC-RP-98-00349, Revision 0, June 18, 1998.

11. M. J. Barnes, L. O. Dworjanyn, S. D. Fink, F. F. Fondeur, M. W. Geeting, M. S Hay, R. F. Swingle and W. R. Wilmarth, "Examination of the Potential for Formation of Energetic Compounds in Dry Sludge," WSRC-TR-98-00407, November 2, 1998.

12. T. Motyka, "Technical Data Summary for In-Tank Sludge Processing," DPST-84$100 ;$ J. R. Fowler.

13. "H-Tank Farm Technical Safety Requirements," WSRC-TR-96-13, Rev. 8, December 1999 and "F-Tank Farm Technical Safety Requirements," WSRC-TR-96-14, Rev. 4, December 1999.

14. R. M. Wallace, "Ammonium Nitrate in the Vessel Vent System", DPST-76-421, November 10, 1976. 
15. Kirk-Othmer Encyclopedia of Chemical Technology, Wiley-Interscience, New York, 3rd edition, 1984, Volume 24, pages 13-14.

16. M. C. H. Fong, Memo to P. J. Shippy, "Organic Receipts to the Tank Farms from the F, H, and S Area Canyons", October 30, 1984.

17. V. S. Ivanov, Radiation Chemistry of Polymers, VSP, Ultrecht, The Netherlands, 1992.

18. D. T. Hobbs, P. W. Norris, S. A. Pucko, N. E. Bibler, D. D. Walker, and P. D. d'Entremont, "Hydrogen Generation Rates in Savannah River Site High-Level Nuclear Waste (U)," Proceedings of the Waste Management Meeting in Tuscon, AZ, ANS, March 1-5, 1992.

19. The Chemistry of Powder and Explosives, Tinney L. Davis, Angriff Press, Las Vegas, NV, 1943.

20. Encyclopedia of Explosives and Related Items, Seymour M. Kaye, Ed., U.S. Army Research and Development Command, TACOM, ARDEC, Picatinny Aresenal, New Jersey, USA, Volume 9, pages R5 - R75.

21. WSRC-SA-33, "Liquid Radioactive Waste Handling Facilities Safety Analysis Report", Rev. 3, August 1999.

22. N. E. Bibler, "Curium-244 Radiolysis of Nitric Acid. Oxygen Production from Direct Radiolysis of Nitrate Ions," J. Phys. Chem., 1974, 78, 211-215.

23. P. D. d'Entremont, memo to R. G. Garvin, "Hydrogen Monitoring and Technical Bases (U)", NMP-WMT-910109, February 1, 1991.

24. I. N. Sax, Dangerous Properties of Industrial Materials, 3rd edition, Reinhold, New York, 1968.

25. Operational Safety Requirements Savannah River Site 241-82H Control Room (U), WSRC-RP-94-303, Rev. 24, August 1999.

26. "Justification for Continued Operation - Tank 49 Benzene Generation Rate Higher than Expected (U),"WSRC-RP-98-01357, Rev. 1, May 1999.

27. R. F. Swingle and M. R. Poirier, "Tank Farm Organic PISA Study Final Report," WSRC-TR-99-00333, Rev. 0, September 30, 1999.

28. J. P. Bibler and R. F. Swingle, "Testing Surfynol ${ }^{\circledR} 420$ in Tank $48 \mathrm{H}$ and Tank $22 \mathrm{H}$ Simulants for Chemical and Radiolytic Effects," WSRG-TR-96-0129, Rev. 0, July $11,1996$.

29. Air Products Material Safety Data Sheet for Surfynol ${ }^{\circledR} 104 \mathrm{E}$ Surfactant. 
30. J. P. Bibler, "Chemical and Radiolytic Effects on Surfynol $₫ 420$ in Tank $48 \mathrm{H}$ and Tank 22H Simulants," WSRC-TR-95-0299, August 2, 1995.

31. D. T. Hobbs, "Organic Content of Tank 33 and Tank 34 Supernate Samples", IWTLWP-91-033, March 7, 1991.

32. R. F. Swingle, J. E. Young, T. A. Nance, Z. H. Qureshi, and S. L. Crump, "Analysis of Organic Samples from the 5-H and 3-F Pump Tanks and Waste Tank 43H," WSRC-TR-99-00188, Revision 0, June 1, 1999.

33. R. F. Swingle, "Analysis of Organic Samples from Waste Tanks 26F, 33F, 46F and 43H - Summer 1999," WSRC-TR-99-00397, October 20, 1999.

34. A. S. Barab, "Operating Incident Waste Management No. 2," memo to J. E. Conway, July 7,1970 .

35. R. M. Wallace, "Investigation of Explosive Material Found in 242-H Evaporator and Feed Tank No. 21", DPST-70-443, September 1, 1970.

36. F. G. McNatt, "History of Waste Tank 211961 Through 1974," DPSPU-78-11-10, October 1978.

37. W. S. Cavin and A. T. Crumm, "Waste Transfer and Miscellaneous Additions (U)," WSRC-TR-93-425, revision 1, January 21, 1994.

38. W. S. Cavin and A. T. Crumm, "Fresh Waste Receipts (U)," WSRC-TR-93-426, revision 1, January 21, 1994.

39. T. L. Davis, D. W. Tharin, and W. E. Stevens, "History of Waste Tank 101955 Through 1974," DPSPU-78-11-11, October 1978.

40. H. L. Hull, "Noble Metals in the DWPF Melter," DPST-85-214, January 4, 1985.

41. J. W. Mellor,_A Comprehensive Treatise on Inorganic and Theoretical Chemistry, Longmans, Green and Company, London, 1947, Volume VIII.

42. W. G. Sykes, et al., Chem. Eng. Progr., 1963, 59(1), 66.

43. "Ammonium Nitrate Receipts in Waste Tanks," DPSOL-241-FH-133, revision 5, December 1989.

44. M. E. Jamison, "Implications of Organic Constituents and Ammonia on Tank Farm Flammability Controls (U)," WSRC-TR-98-00014, Rev. 1, April 27, 1998.

45. R. F. Swingle and T. L. White, "Contributions of Ammonia and Defoamers to Lower Flammability Limit in SRS High Level Waste Tanks," WSRC-TR-99-00189, June $18,1999$. 
46. CRC Handbook of Chemistry and Physics, R. C. Weast, Ed., 65th edition, CRC Press, Boca Raton, Florida, 1984.

47. F. A. Cotton and G. Wilkinson, Advanced Inorganic Chemistry, 4th edition, WileyInterscience, New York, 1980.

48. Laboratory Notebook assigned to D. T. Hobbs, WSRC-NB-91-114, pages 37-38.

49. D. T. Hobbs, "Organic Content of Tank 33 and Tank 34 Supernate Samples", IWTLWP-91-033, March 7, 1991.

50. S. W. Claybrook and S. A. Wood, "Organic Evaporation in Waste Tank C-103," WHC-SD-WM-ER-344, revision 0, June 1994.

51. J. L. Huckaby, "Tank 241-C-103 Headspace Flammability," WHC-EP-0734, January 1994.

52. R. F. Swingle, "Tri-n-butyl Phosphate Combustibility in In-Tank Precipitation Salt Solutions," WSRC-RP-94-526, June 16, 1994.

53. J. G. Watkin, "The "Red Oil" Problem - History, Chemistry and Relevance to Hanford Waste Tank Safety Concerns," LAUR-92-3168-Rev. 1.

54. J. G. Watkin and P. L. Gordon, "Investigation of "Red Oil" and Its Stability in Simulated Hanford Tank Wastes (Red Oil Safety Evaluation)," LAUR-93-2809-Rev. 1.

55. M. Layton, "Contribution of Organics to Tank Farm Deflagrations," NI-HLW-98007 , May 7, 1998.

56. D. D. Walker, "Combustibility of Tetraphenylborate Solids (U)", WSRC-RP-89-261, May 3, 1989.

57. D. D. Walker, "Combustibility of ITP Slurries (U)," WSRC-RP-93-868, August 12, 1993.

58. L. O. Dworjanyn, "Air Dried ITP Slurry Combustibility Testing (U)," WSRC-RP-94528, May 13, 1994.

59. L. L. Kilpatrick, "Drying Rates of Washed and Unwashed In-Tank Precipitate (ITP) Slurry (U)," WSRC-RP-94-406, June 3, 1994.

60. M. J. Barnes, "Radiolytic Stability of Phenol in Aqueous Solutions - A Literature Review", WSRC-RP-91-559, May 13, 1991.

61. M. J. Barnes, "Determination of the Fate and Impact of Phenol/sodium phenoxide on Tank Farm Operations - Scoping Technical Plan", IWT-LWP-91-081. 
62. M. J. Barnes, "Task Technical Plan for Studies of Organic Compounds in the Defense Waste Processing Facility Recycle Stream (U)," WSRC-RP-94-101, January 20, 1994.

63. M. J. Barnes, "Characterization of the Behavior of Defense Waste Processing Facility Recycle Stream Organic Compounds in High Level Waste Processing Facilities (U)," WSRC-TR-95-0465, Rev. 0, December 6, 1995.

64. C. W. Hsu, "Status Report Nitroaromatic Content of Recycle Stream from DWPF," SRTC-PTD-93-110, October 27, 1993.

65. C. W. Hsu, "Bench-Scale Study of Nitroaromatic Compounds Generated During the Melter Feed Preparation in the DWPF (U)," WSRC-TR-95-0186.

66. J. W. Mellor, A Comprehensive Treatise on Inorganic and Theoretical Chemistry, Wiley \& Sons, New York, 1967, Volume III.

67. J. R. Fowler, "Source Terms for Hazardous Chemicals in High-Level Waste Tanks at the SRS (U)," X-SD-G-00002, Revision 1, January 1995.

68. MST Procurement Specifications \#A54603, revision 2, August 1, 1990.

69. Laboratory Notebook assigned to D. T. Hobbs, WSRC-NB-91-114, page 38.

70. J. V. Kaufman, "The Effect of Nuclear Radiation on Explosives, " Proc. Royal Soc., 1958, A246, 219 - 225.

71. F. F. Fondeur and W. R. Wilmarth, "Synergistic and Alkaline Stability Studies of Mixtures of Simulated High Waste sludge with Selected Energetic Compounds," WSRC-TR-99-00592, Rev. 0, July 12, 1999.

72. E. P. Bowden and A. D. Yoffe, Fast Reactions in Solids, Academic Press, New York, 1970.

73. J. W. Mellor, A Comprehensive Treatise on Inorganic and Theoretical Chemistry, Wiley \& Sons, New York, 1967, Vol. VIII, Supplement II.

74. E. K. Dukes and R. M. Wallace, "Formation of Hydrazoic Acid from Hydrazine in Nitric Acid Solutions", DP-728, 1962.

75. B. L. Evans, A. D. Yoffe, and P. Gray, "Physics and Chemistry of the Inorganic Azides", Chemical Reviews, 1959, 59, 515-568.

76. T. E. Britt, personal communication, October 27, 1999.

77. A. L. Patrick and D. T. Hobbs, "Laboratory Evaluation of Defoamers for Use in High Level Waste Evaporators," WSRC-TR-90-490, November 18, 1990. 
78. R. T. Morrison and R. N. Boyd, Organic Chemistry, $3^{\text {rd }}$ Edition, Allyn and Bacon Inc., Boston, MA, 1975.

79. M. K. Carlson, "Project S-1780 - Savannah River Plant - 200S Area Defense Waste Processing Facility Materials of Construction Composite Group Meeting," March 6 and 7, 1989, OPS-WMQ-89-0057, June 23, 1989.

80. P. E. Zapp, "Corrosion Tests of DWPF Recycle Solution (U)," WSRC-TR-92-376, July 28, 1992.

81. P. E. Zapp, "DWPF Recycle Stream Corrosion Tests (U)," WSRC-TR-93-233, April 21, 1993.

82. P. E. Zapp, "Corrosion Tests of Carbon Steel Exposed to a Simulated DWPF Recycle Stream (U)," WSCR-TR-93-519, September 30, 1993.

83. P. E. Zapp and D. T. Hobbs, "Final Assessment of Shock-Sensitive Deposit Formation (U)," WSRC-TR-94-048, January 28, 1994.

84. J. R. Fowler, "Chemical and Radiochemical Analyses of SRP Liquid Waste," DPST80-409, July 1980.

85. J. C. Bailar, Comprehensive Inorganic Chemistry 2 Pergammon Press, Oxford, 1973.

86. J. W. Mellor, A Comprehensive Treatise on Inorganic and Theoretical Chemistry, Wiley \& Sons, New York, 1967, Volumes III, XI, XIV, and XV.

87. J. Varjarvandi, et al., J. Chem. Educ., 1971, 48, A451.

88. N. Bibler, unpublished results.

89. T. E. Britt, "Re-Wetting of Dry Sludge Tanks 5F and 8F, WSRC-TR-97-00069, Rev. 1, July, 1998.

90. R. M. Wallace, "Explosion Hazard of Mercury and Silver Oxalates During Cleaning of Tank 16H", DPST-77-517, December 19, 1977.

91. D. T. Hobbs, "Recommended Standard Materials for Evaluation of Dry Sludge Energetic Reactions," WSRC-TR-98-00262, Rev.0, August 19, 1998.

92. Basic Data Report Defense Waste Processing Facility Sludge Plant, DPSP-80-1033, revision 90, Appendix G, October 30, 1984.

93. Lange's Handbook of Chemistry, J. A. Dean, Ed., 13th edition McGraw-Hill, New York, 1985.

94. W. D. Kimball, memo to T. M. Monahon, "Waste Acceptance Criteria for DWPF Recycle," OPS-DTA-940022, March 4, 1994. 
95. V. K. Krieble and C. L. Noll, J. Amer. Chem. Soc., 1939, 61, 560.

96. F. C. Fuson, Advanced Organic Chemistry, John Wiley \& Sons, New York, 1950, pages 203-206.

97. Kirk-Othmer Encyclopedia of Chemical Technology, 3rd edition, Volume 7, WileyInterscience, New York, 1979.

98. Z. D. Draganic and I. G. Draganic, Radiation Research, 1977, 69, 223-229.

99. Q. Shen-chu, Y. Shao-hua, and W. Ji-lan, Radiat. Phys. Chem., 1981, 18(3-4), 793805.

100. Appendix IX Analytical Results for Tank 50 Aqueous Waste Samples, General Engineering Laboratories of Charleston, SC, September 12, 1986.

101. J. G. Leopold and M. Faraggi, Journal of Physical Chemistry, 1977, 81, 803.

102.F. E. Bartell, Journal of Industrial Engineering Chemistry, 1922, 14, 516.

103. G. Draganic and Z. D. Draganic, The Radiation Chemistry of Water, Academic Press, New York, 1971.

104.D. G. Noller and D. J. Bolton, Analytical Chemistry, 1963, 35, 887.

105. J. W. Mellor, A Comprehensive Treatise on Inorganic and Theoretical Chemistry, Wiley \& Sons, New York, 1967, Volumes II, III, IV, and Volume II, Supplement II.

106. D. T. Hobbs, "Possible Formation of Metal Acetylides (U)," SRT-LWP-92-106, August 4, 1992.

107.D. D. Walker, "Stream Compositions for the In-Tank Precipitation Process," IWT-LWP-90-0181, October 26, 1990.

108. D. D. Walker, personal communication, November 18, 1993.

109. S. Beck, J. T. Carter, R. A. Dimenna, O. E. Duarte, H. H. Elder, J. R. Fowler, M. V. Gregory, T. Hang, R. A. Jacobs, P. K. Paul, R. A. Peterson, K. Reuter, P. L. Rutland, D. M. Schaffer, M. A. Shadday, F. G. Smith, III, G. A. Taylor, A. L. Whittenbury and M. H. Wilson, "Bases, Assumptions, and Results of the Flowsheet Calculations for the Short List Salt Disposition Alternatives," WSRC-RP-98-00168, Rev. 1, October 22, 1998.

110. L. H Delmau, G. J. Van Berkel, P. V. Bonnesen and B. A. Moyer, "Improved Performance of the Alkaline-Side CSEX Process for Cesium Extraction from Alkaline High-Level Waste Obtained by Characterization of the Effect of Surfactant Impurities," ORNL/TM-1999/209, October 1999. 
111.C. L. Crawford and D. D. Walker, "Hydrogen Generation by Radiolysis of Tetraphenylborate Solutions and Slurries (U)," WSRC-TR-96-0109, Rev. 0, June 19, 1996.

112.F.F. Fondeur, W. R. Wilmarth and S. D. Fink, "Gamma Radiation Stability Studies of Mercury Fulminate," WSRC-RP-99-01090, Rev. 0, January 2000.

113.L. O. Dworjanyn, "Benzene Retention in TPB Slurry - Status Report (U)," WSRCRP-97-217, Rev. 0, March 26, 1997.

114.L. O. Dworjanyn, "Benzene Retention in TPB Slurry - Status Report (U)," WSRCRP-97-903, Rev. 0, November 4, 1997.

115. M. R. Poirier, "Laboratory-Scale Study of Parameters Influencing Benzene Retention and Release in Potassium Tetraphenylborate Slurries (U)," WSRC-TR-9700375, Rev. 0, November 5, 1997.

116. J. C. Marek and W. B. Van Pelt, "Pilot-Scale Benzene Retention an Release Demonstration (U)," WSRC-TR-97-0360, Rev. 0, December 1997.

117. "CST/WPT Facilities Justification for Continued Operations," WSRC-TR-9900205, Rev. 11, August 1999.

118. F. F. Fondeur and W. R. Wilmarth, "Independent Panel Evaluation of Dry Sludge PISA Program,” WSRC-RP-99-00727, August 30, 1999.

119. L. O. Dworjanyn, "Vendor Testing of Sensitive Comopounds in Simulated Dry Sludge,"WSRC-RP-99-00248, Rev. 0, June 22, 1999.

120. Gmelins Handbook of Inorganic Chemistry, Mercury, Volume 34, Part B Number 3, Verlag, 1968, page 1232.

121. R. T. Morrison and R. N. Boyd, Organic Chemistry, $3^{\text {rd }}$ edition, Allyn and Bacon, Boston, Chapter 19, pages 617-657. 


\section{Appendix 1}

\section{Supernatant Liquid Composition}

Concentration (mole/L)

Compound

$\mathrm{NaNO}_{3}$

$\mathrm{NaOH}$

$\mathrm{NaNO}_{2}$

$\mathrm{NaAlO}_{2}$

$\mathrm{Na}_{2} \mathrm{CO}_{3}$

$\mathrm{Na}_{2} \mathrm{SO}_{4}$

Total Organic Carbona

$\mathrm{NaCl}$

$\mathrm{NaF}$

$\mathrm{Na}_{2} \mathrm{C}_{2} \mathrm{O}_{4}$

$\mathrm{Na}_{3} \mathrm{PO}_{4}$

$\mathrm{Na}_{2} \mathrm{CrO}_{4}$

$\mathrm{Na}_{2} \mathrm{MoO}_{4}$

$\mathrm{Na}_{2} \mathrm{SiO}_{3}$

$\mathrm{Na}_{2} \mathrm{~B}_{4} \mathrm{O}_{7}$

$\mathrm{NaTcO}_{4}$

$\mathrm{NaTPB}^{\mathrm{b}}$

$\mathrm{NaOC}_{6} \mathrm{H}_{5}{ }^{\mathrm{b}}$

$\mathrm{Sr}\left(\mathrm{NO}_{3}\right)_{2}{ }^{\mathrm{c}}$

$\mathrm{CsNO}_{3}{ }^{\mathrm{d}}$

$\mathrm{Na}[\mathrm{HgO}(\mathrm{OH})]$

$\mathrm{Na}\left[\mathrm{Ag}(\mathrm{OH})_{2}\right]$
Average

2.7

1.9 .

0.84

0.44

0.23

0.20

0.076

0.031

0.021

0.021

0.012

0.0046

0.0014

0.0076

$1.9 \times 10^{-4}$

$1.5 \times 10^{-4}$

-

-

$2.4 \times 10^{-8}$

$1.0 \times 10^{-4}$

$3.3 \times 10^{-4}$

$6.5 \times 10^{-6}$
Bounding

8.5

15

3.0

1.3

0.5

0.5

2.4

0.3

0.1

0.5

0.5

0.038

0.011

0.061

0.0015

0.0012

0.1

0.05

$4.0 \times 10^{-7}$

$5.0 \times 10^{-3}$

$2.5 \times 10^{-3}$

$9.3 \times 10^{-3}$

a Average value based on highest measured value for fresh waste receipt tank supernate samples [49]. Maximum value based on bounding NaTPB concentration [67].

b NaTPB and sodium phenoxide are not present in stored waste outside of Tanks $48 \mathrm{H}, 49 \mathrm{H}$ and $50 \mathrm{H}$, but will be present in H-Area waste if the salt processing utilizes the tetraphenylborate precipitation process.

c reference 107 .

deference 108 . 


\section{Appendix 2}

\section{Average and Maximum Projected Weight Percent} of Insoluble Components in Sludge

\begin{tabular}{llc} 
& \multicolumn{2}{c}{ Weight Percent } \\
Compound & Average & Maximum \\
$\mathrm{Fe}_{2} \mathrm{O}_{3} \cdot 3 \mathrm{H}_{2} \mathrm{O}$ & 30.1 & 48.5 \\
$\mathrm{Al}_{2} \mathrm{O}_{3} \cdot 3 \mathrm{H}_{2} \mathrm{O}$ & 32.9 & 67.1 \\
$\mathrm{MnO}_{2}$ & 5.1 & 12.1 \\
$\mathrm{NiO}^{\mathrm{H}} \mathrm{H}_{2} \mathrm{O}$ & 1.9 & 5.8 \\
$\mathrm{UO}_{3} \cdot \mathrm{H}_{2} \mathrm{O}$ & 3.4 & 10.9 \\
$\mathrm{HgO}$ & 1.6 & 6.0 \\
$\mathrm{SiO}_{2}$ & 5.9 & 9.4 \\
$\mathrm{Cr}_{2} \mathrm{O}_{3} \cdot 3 \mathrm{H}_{2} \mathrm{O}$ & 0.38 & 0.7 \\
$\mathrm{PbCO}_{3}$ & 0.063 & 0.5 \\
$\mathrm{PbSO}_{4}$ & 0.14 & 0.4 \\
$\mathrm{BaSO}_{4}$ & 0.15 & 0.8 \\
$\mathrm{Ag}_{2} \mathrm{O} \cdot \mathrm{H}_{2} \mathrm{O}$ & $2.0 \times 10^{-2}$ & 0.4 \\
$\mathrm{CaCO}_{3}$ & 4.0 & $\mathrm{nr}$ \\
$\mathrm{Zeolite}$ & 3.6 & $\mathrm{nr}$ \\
& $\mathrm{nr}=\mathrm{not}$ reported &
\end{tabular}




\section{Appendix 3}

\section{Comprehensive Listing of Conceivable Explosive Compounds}

Compound

Barium azide

Barium nitride

Barium peroxide

Calcium peroxide

Chlorine heptaoxide

Chlorine oxide

Hexaamminechromium(III) nitrate

Pentamminenitratochromium(III) nitrate

Diamminenitratocobalt(II) nitrate

Tramminetrinitrocobalt

Trihydrazinecobalt(II) nitrate

Ammonium hexanitocobaltate

Pentaamminenitratocobalt(III) nitrate

Hexamminecobalt(III) permanganate

Hexamminecobalt(III) nitrate

Hexahydroxyamminecobalt(III) nitrate

Hexamminecobalt(III)

hexanitratocobaltate(III)

Tetraammine copper(II) nitrite

Tetraammine copper(II) nitrate

Tetraammine copper(II) sulfate

Cuprous azide

Cupric azide

Tetraammine copper(II) azide

Lead Chlorite

Lead Tetrachloride

Lead hyponitrite

Manganese oxide

Potassium permanganate

Potassium peroxide
Formula

$\mathrm{Ba}\left(\mathrm{N}_{3}\right)_{2}$

$\mathrm{Ba}_{3} \mathrm{~N}_{2}$

$\mathrm{BaO}_{2}$

$\mathrm{CaO}_{2}$

$\mathrm{Cl}_{2} \mathrm{O}_{7}$

$\mathrm{ClO}_{2}$

$\left[\left(\mathrm{H}_{3} \mathrm{~N}\right)_{6} \mathrm{Cr}\right]\left(\mathrm{NO}_{3}\right)_{3}$

$\left[\left(\mathrm{H}_{3} \mathrm{~N}\right)_{5} \mathrm{Cr}\left(\mathrm{NO}_{3}\right)\right]\left(\mathrm{NO}_{3}\right)_{2}$

$\left[\left(\mathrm{H}_{3} \mathrm{~N}\right)_{2} \mathrm{Co}\left(\mathrm{NO}_{3}\right)\right]\left(\mathrm{NO}_{3}\right)$

$\left(\mathrm{H}_{3} \mathrm{~N}\right)_{3} \mathrm{Co}\left(\mathrm{NO}_{3}\right)_{3}$

$\left[\left(\mathrm{H}_{4} \mathrm{~N}_{2}\right)_{3} \mathrm{Co}\right]\left(\mathrm{NO}_{3}\right)_{3}$

$\left(\mathrm{H}_{4} \mathrm{~N}^{+}\right)_{3}\left[\mathrm{Co}\left(\mathrm{NO}_{3}\right)_{6}\right]^{3-}$

$\left[\left(\mathrm{H}_{3} \mathrm{~N}\right)_{5} \mathrm{Co}\left(\mathrm{NO}_{3}\right)\right]\left(\mathrm{NO}_{3}\right)_{2}$

$\left[\left(\mathrm{H}_{3} \mathrm{~N}\right)_{6} \mathrm{Co}\right]\left(\mathrm{MnO}_{4}\right)_{3}$

$\left[\left(\mathrm{H}_{3} \mathrm{~N}\right)_{6} \mathrm{Co}\right]\left(\mathrm{NO}_{3}\right)_{3}$

$\left[\left(\mathrm{HONH}_{2}\right)_{6} \mathrm{Co}\right]\left(\mathrm{NO}_{3}\right)_{3}$

$\left[\left(\mathrm{H}_{3} \mathrm{~N}\right)_{6} \mathrm{Co}\right]\left[\mathrm{Co}\left(\mathrm{NO}_{3}\right)_{6}\right]$

$\left(\mathrm{H}_{3} \mathrm{~N}\right)_{4} \mathrm{Cu}\left(\mathrm{NO}_{2}\right)_{2}$

$\left(\mathrm{H}_{3} \mathrm{~N}\right)_{4} \mathrm{Cu}\left(\mathrm{NO}_{3}\right)_{2}$

$\left(\mathrm{H}_{3} \mathrm{~N}\right)_{4} \mathrm{CuSO}_{4}$

$\mathrm{CuN}_{3}$

$\mathrm{Cu}\left(\mathrm{N}_{3}\right)_{2}$

$\left(\mathrm{H}_{3} \mathrm{~N}\right)_{4} \mathrm{Cu}\left(\mathrm{N}_{3}\right)_{2}$

$\mathrm{PbClO}_{2}$

$\mathrm{PbCl}_{4}$

$\mathrm{PbN}_{2} \mathrm{O}_{2}$

$\mathrm{MnO}_{2}$

$\mathrm{K}_{2} \mathrm{Mn}_{2} \mathrm{O}_{7}$

$\mathrm{K}_{2} \mathrm{O}_{2}$ 
Appendix 3 (continued)

Compound

Mercuric fulminate

Mercuric nitride

Mercuric oxalate

Mercuric oxycyanide

Mercurous chlorate

Mercurous nitrate

Mercurous nitride

Mercury peroxide

Nitrobenzene

1,3,5-trinitrobenzene

2-nitrophenol

4-nitrophenol

2-nitrosophenol

4-nitrosophenol

2,4-dinitrophenol

2,4,6-trinitrophenol

1,2-dinitrobenzene

1,3-dinitrobenzene

2-nitroaniline

3-nitroaniline

4-nitroaniline

Diamminepalladium(II) nitrite

Diamminepalladium(II) nitrate

cis-Diammineplatinum(II) nitrate

Phenol

Selenium nitride

Silicon diiodide

Sodium peroxide

Sodium performate

Sodium peracetate

Strontium peroxide
Formula

$\mathrm{Hg}(\mathrm{CNO})_{2}$

$\mathrm{Hg}_{3} \mathrm{~N}_{2}$

$\mathrm{Hg}_{2} \mathrm{C}_{2} \mathrm{O}_{4}$

$\mathrm{Hg}(\mathrm{CN})_{2} \cdot \mathrm{HgO}$

$\mathrm{HgClO}_{3}$

$\mathrm{HgNO}_{3}$

$\mathrm{HgN}_{3}$

$\mathrm{HgO}_{2}$

$\mathrm{C}_{6} \mathrm{H}_{5} \mathrm{NO}_{2}$

$\mathrm{C}_{6} \mathrm{H}_{3} \mathrm{~N}_{3} \mathrm{O}_{6}$

$\mathrm{C}_{6} \mathrm{H}_{5} \mathrm{NO}_{3}$

$\mathrm{C}_{6} \mathrm{H}_{5} \mathrm{NO}_{3}$

$\mathrm{C}_{6} \mathrm{H}_{5} \mathrm{NO}_{2}$

$\mathrm{C}_{6} \mathrm{H}_{5} \mathrm{NO}_{2}$

$\mathrm{C}_{6} \mathrm{H}_{4} \mathrm{~N}_{2} \mathrm{O}_{5}$

$\mathrm{C}_{6} \mathrm{H}_{3} \mathrm{~N}_{3} \mathrm{O}_{7}$

$\mathrm{C}_{6} \mathrm{H}_{4} \mathrm{~N}_{2} \mathrm{O}_{4}$

$\mathrm{C}_{6} \mathrm{H}_{4} \mathrm{~N}_{2} \mathrm{O}_{4}$

$\mathrm{C}_{6} \mathrm{H}_{6} \mathrm{~N}_{2} \mathrm{O}_{2}$

$\mathrm{C}_{6} \mathrm{H}_{6} \mathrm{~N}_{2} \mathrm{O}_{2}$

$\mathrm{C}_{6} \mathrm{H}_{6} \mathrm{~N}_{2} \mathrm{O}_{2}$

$\left(\mathrm{H}_{3} \mathrm{~N}\right)_{2} \mathrm{Pd}\left(\mathrm{NO}_{2}\right)_{2}$

$\left(\mathrm{H}_{3} \mathrm{~N}\right)_{2} \mathrm{Pd}\left(\mathrm{NO}_{3}\right)_{2}$

$\left(\mathrm{H}_{3} \mathrm{~N}\right)_{2} \mathrm{Pt}\left(\mathrm{NO}_{3}\right)_{2}$

$\mathrm{C}_{6} \mathrm{H}_{5} \mathrm{OH}$

$\mathrm{Se}_{4} \mathrm{~N}_{4}$

$\mathrm{SiI}_{2}$

$\mathrm{Na}_{2} \mathrm{O}_{2}$

$\mathrm{HCOOONa}$

$\mathrm{CH}_{3} \mathrm{COOONa}$

$\mathrm{SrO}_{2}$ 


\section{Appendix 3 (continued)}

Compound

Didydrazine tin chloride

- Zinc peroxide

Dihydroxyammine zinc chloride

Nitrogen trichloride

Nitrogen triiodide

Ammonia nitrogen triiodide

Hydroxylamine

Hydroxylamine nitrate

Ammonium nitrite

Ammonium nitrate

Ammonium iodate

Ammonium chlorate

Ammonium perchlorate

Hydrazine

Hydrazinium nitrate

Hydrogen Azide (Hydrozoic Acid)

Hyponitrous Acid

Hydrogen Peroxide

Silver oxalate

Silver azide

Silver nitride

Silver amide

Silver azide chloride

Silver perchlorate

Silver chlorate

Silver chlorite

Hydrazine silver nitrate

Silver iodate

Silver peroxide

Silver fulminate

Silver hyponitrite

Diammine silver permanganate
Formula

$\left(\mathrm{H}_{4} \mathrm{~N}_{2}\right)_{2} \mathrm{SnCl}_{2}$

$\mathrm{ZnO}_{2}$

$\left(\mathrm{HONH}_{2}\right)_{2} \mathrm{ZnCl}_{2}$

$\mathrm{NCl}_{3}$

$\mathrm{NI}_{3}$

$\mathrm{NH}_{3} \mathrm{NI}_{3}$

$\mathrm{HONH}_{2}$

$\mathrm{NH}_{2} \mathrm{OH} . \mathrm{HNO}_{3}$

$\mathrm{NH}_{4} \mathrm{NO}_{2}$

$\mathrm{NH}_{4} \mathrm{NO}_{3}$

$\mathrm{NH}_{4} \mathrm{IO}_{3}$

$\mathrm{NH}_{4} \mathrm{ClO}_{3}$

$\mathrm{NH}_{4} \mathrm{ClO}_{4}$

$\mathrm{N}_{2} \mathrm{H}_{4}$

$\mathrm{N}_{2} \mathrm{H}_{4} \cdot \mathrm{HNO}_{3}$

$\mathrm{HN}_{3}$

$\mathrm{H}_{2} \mathrm{~N}_{2} \mathrm{O}_{2}$

$\mathrm{H}_{2} \mathrm{O}_{2}$

$\mathrm{Ag}_{2} \mathrm{C}_{2} \mathrm{O}_{4}$

$\mathrm{AgN}_{3}$

$\mathrm{Ag}_{3} \mathrm{~N}$

$\mathrm{AgNH}_{2}$

$\mathrm{AgClN}_{3}$

$\mathrm{AgClO}_{4}$

$\mathrm{AgClO}_{3}$

$\mathrm{AgClO}_{2}$

$\left(\mathrm{H}_{4} \mathrm{~N}_{2}\right) \mathrm{AgNO}_{3}$

$\mathrm{AgIO}_{3}$

$\mathrm{Ag}_{2} \mathrm{O}_{2}$

$\mathrm{Ag}(\mathrm{CNO})$

$\mathrm{Ag}_{2} \mathrm{~N}_{2} \mathrm{O}_{2}$

$\left(\mathrm{H}_{3} \mathrm{~N}\right)_{2} \mathrm{AgMnO}_{4}$ 